WIMMER Ágnes - CSESZNÁK Anita

\title{
VÁLLALATI TELJESÍTMÉNYMÉRÉS A DÖNTÉSTÁMOGATÁS TÜKRÉBEN
}

A hazai vállalatok teljesítménymérési és teljesítménymenedzsment-gyakorlatát vizsgálja a cikk a „Versenyben a világgal” kutatási program 2009. évi felmérésének adatait felhasználva. A szerzók célja a döntéstámogatás hátterének elemzése: a teljesítménymérés gyakorlatának, következetességének, támogató jellegének az értékelése, vizsgálva a korábbi (1996., 1999. és 2004. évi) hasonló kutatások során megfigyelt tendenciák alakulását is, az információs rendszer szerepének az értékelésekor a különbözó területekért felelôs vezetốk véleményét is összeveti, s különbözó vállalati jellemzók (vállalatméret, tulajdonosok típusa, reagálóképesség, teljesítmény stb.) alapján kialakított csoportok sajátosságait is értékeli. ${ }^{1}$

Kulcsszavak: üzleti teljesítmény, teljesítménymérés, döntéstámogatás

A vállalati döntéshozóknak - legyen szó felső vezetôkról vagy a szervezeti hierarchia bármely szintjén, a folyamatok bármely részén tevékenykedő munkatársakról - releváns információkra van szükségük. Cikkünk célja a döntéstámogatás hátterének vizsgálata, kiemelten a döntéseket támogató információk, a döntéseket segítő teljesítménymenedzsment-megközelítések és -eszközök szempontjából. A vállalatok teljesítménymérési és teljesítménymenedzsment-gyakorlatának jellemzése, konzisztenciájának,s döntéstámogató szerepének értékelése során a Budapesti Corvinus Egyetem Versenyképesség Kutató Központja „Versenyben a világgal” kutatási programja (a továbbiakban: Versenyképességkutatás) legutóbbi, 2009. évi eredményei mellett röviden kitérünk a három korábbi (az 1996., az 1999. és a 2004. évi) hasonló felmérés elemzésekor megfigyelt tendenciák alakulására is. A vállalatvezetók által fontosnak/hasznosnak tartott, illetve rendszeresen használt információforrások, teljesítménymutatók, elemzési eszközök értékelése a korábbi kutatásaink során kialakított elemzési keret alapján történt, melyben a teljesítménymérési gyakorlat orientációját, kiegyensúlyozottságát, konzisztenciáját és támogató szerepét emeltük ki (1. Wimmer, 2000, 2004, 2005).

A döntéstámogatás hátterének értékeléséhez fontos információt nyújt a vállalatvezetốk észlelése: hogyan látják, milyen mértékben támogat különbözô - a vállalat vezetése, a teljesítmény fejlesztése szempontjából fontos - tevékenységeket vállalatuk információs rendszere? Az információs rendszer által nyújtott támogatás észlelt mértékének vizsgálatakor összevetettük különböző területekért felelős vezetók véleményét (a felsô vezetô, a marketing/kereskedelmi, a pénzügyi és a termelési vezetốk által adott válaszok alapján) is.

A cikk elsố részében a teljesítménymérés döntéstámogatásban játszott szerepével foglalkozunk, majd röviden áttekintjük a kutatás hátterét, módszereit. Ezt követően a vizsgálati modell alapján értékeljük a vállalati gyakorlatot, majd kiemelt vállalatcsoportok (így például a különböző méretú vagy különböző teljesítményt nyújtó vállalatok) gyakorlatának különbségeire térünk ki. ${ }^{2}$

\section{A teljesítménymérés szerepe a döntés- támogatásban, a teljesítménymenedzsment}

Az üzleti célok eléréséhez, az üzleti teljesítmény javításához fontos (bár önmagában nem elégséges) feltétel, hogy a döntéshozóknak, érintetteknek releváns információi legyenek a vállalati teljesítmény eddigi alakulásáról s a teljesítményt befolyásoló tényezókroól. A megfelelően megválasztott teljesítménymutatók, teljesítménymérési és teljesítménymenedzsment-eszközök, a döntéshozatalt és a teljesítmény menedzselését ${ }^{3}$ és fejlesztését támogató információs háttér fontos értékteremtő tényező lehet. Ennek fordítottja is érvényes: 
A teljesítménymérési gyakorlat jellemzói - elemzési keret

1. ábra is nagyobb szerepet kap (l. pl. Neely és munkatársai [2004] teljesítményprizma megközelítését). ${ }^{4}$

\begin{tabular}{|c|c|}
\hline Orientáció & $\begin{array}{l}\text { ellenörzés / beszámoltatás / } \\
\text { döntéstámogatás / visszacsatolás stb. }\end{array}$ \\
\hline Kiegyensúlyozottság & $\begin{array}{l}\text { a. Tartalom: } \\
\text { - versenytényezök } \\
\text { - folyamatszemlélet } \\
\text { b. Információk: } \\
\text { - forrása (belsö, külsö) } \\
\text { - jellege (objektiv, szubjektív) }\end{array}$ \\
\hline Konzisztencia & $\begin{array}{l}\text { a. A fontosság és a használat } \\
\text { ôsszhangaj } \\
\text { b. Stratégiai támogatás }\end{array}$ \\
\hline
\end{tabular}

Forrás: Wimmer (2000, 2004), módosítva

mivel az elérhetố információk befolyásolják a döntéseket, a nem megfelelően válogatott, hiányos, torz információk félrevezető képet adhatnak, s rossz döntésekhez vezethetnek.

Az üzleti teljesítmény több szempontú mérése, a teljesítmény javítását segítő menedzsmenteszköztár az elmúlt évtizedekben kiemelt figyelmet kapott az üzleti szakirodalomban. A vállalati teljesítménymérés forradalmának" egyik elindítója Johnson és Kap „, forradalmának " egyik elinditoja Johnson és Kaplan Lost - The Rise and Fall of Management Accounting, melyben a szerzók megfogalmazták, hogy a (vezetóii) méyben a szerzôk megfogalmazták, hogy a (vezetôi) számvitel elterjedt eszközei nem relevansak többé megvaltozott piaci és versenykörnyezetben, nem nyứjtanak megfeleló információt sem a múködési (termelési, szolgáltatási), sem a piaci döntések többségéhe A megfogalmazott kritikát a vezetôi számvitel és a tejesítménymérés szemléletmódjának és eszköztárának fejlesztése követte, mely releváns, a vállalati folyamatok jobb megértését segító, a vezetôi döntéseket támogató költség- és teljesítménymenedzsment-módszereket hozott, támogatva az egyedi vállalati igényekhez való igazítást is. A fejlódés több irányú: többek között pénzügyi és költség lapú teljesítménymérési között fejlődésében (költségmenedzsment-rondszerek fejlo-

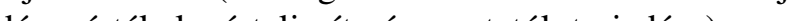
dése, ertékalapú teljesítménymutatók terjedése), a ne pénzugyi (a múkôdéshez, piaci tênyezơkhöz kapesolódó) teljesítménymutatók nôvekvó használatában, s a tôbb szempontú, ok-okozati kapcsolatokat is vizsgálo átfogó teljesítménymérési keretek megjelenésében, terjedésében érhetô tetten a kilencvenes évektôl. Az elmú évtizedben az érintettek szélesebb körére is figyelem irányul (részben, de nem kizárólag a vállalatok társadalmi felelốssége és a fenntarthatóság kérdéseinek elôtérbe kerülésével), s az üzleti partnerekkel, érintettekkel való kapcsolatok, a kölcsönös elvárások kétirányú vizsgálata

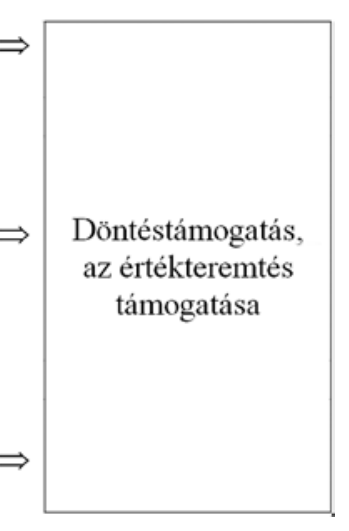

Az elemzési kere

Cikkünkben - folytatva Versenyképesség-kutatás keretében több mint tizenöt éve folyó kutatásainkat - e szemléletmód és tendenciák hazai érvényesïlését is vizsgáljuk. Elemzésïnkhöz velhaśluk. Elenzésunkhöz tők értékelését (például miyennek tartják a rendelkezésüikre álló információkat), másrészt az általuk megadott információk alapján jellemeztük a teljesítménymérési gyakorlatot, s vizsgáltuk a szakirodalomban megfogalmazott elvárások (például a teljesítménymérési gyakorlat konzisztenciájának, hasznosságának) teljesülését. Az elemzési keret elemeit az 1. ábra foglalja össze.

A teljesítménymérési gyakorlat értékelése során a korábbi kutatásaink folyamán kialakított, a nemzetköi szakirodalmi tapasztalatokra is épitón elemzési keret (Wimmer, 2000, 2004) felhasználásával a következố tényezóket vizgáljuk:

1. A teljesítménymérés orientációja a teljesítménymérés fő célját, szerepét fejezi ki. Ilyen lehetséges cél például az ellenôrzés, a beszámoltatás, a visszacsatolások biztosítása, a döntések támogatása, a tervezés segíse. Az üzleti döntések és az értékteremtés támogatása szempontjából a döntések (a múködési szint döntései) támogatását szolgáló információk nyújtása, a visszacsatolások kiemelt tényező́k.

2. A kiegyensúlyozottság elvárása azt jelzi, hogy a teljesítménymérési rendszer több szempontú legyen mind az alkalmazott eszközök tartalmi jellemző́i, mind az információk forrása és jellege tekintetében. Ezen belïl a tartalmi jellemz" azt fejezi ki, hogy milyen tí a joúcó információkat gyújt és használ rendszeresen a vállalat. Kiemelt elemek a különbözó versenyelőnyforrások, versenytényezók (költség, minőség, idő, rugalmasság stb.) figyelemmel kísérése, valamint a folyamatszemlélet jelenléte (a folyamatok különbözố elemeinek követése, illetve a vevóí és a beszállító kapcsolatok figyelemmel kísérése, a célok kommunikálása az üzleti partnerek felé). A felhasznált információkat az információ forrása (külső és belső információ, különböző érintettek véleményének becsatornázása) s az információ jellege (objektív és szubjektív információk felhasználása) alapján is csoportosíthatju

VEZETÉSTUDOMÁNY
A sokféle módszer, mutató, információforrás alkalmazása önmagában nem jelent értéket. A hangsúly a kiegyensúlyozottságon, a különbözó elemzési eszközök, teljesítménymutatók összhangján van. A több szempontúság nem jelenti automatikusan az integrált szemléletet, a különböző tényező́k kapcsolatának, egymásז hatásának figyelembevételét. E szempontot a következô vizsgált jellemzó, a konzisztencia képviseli.

3. A konzisztencia a következetesség a teljesítménymérési gyakorlat egyik legfontosab az alkalmazott módszerek hasznosságára, támogatố jellegére utal. A konzisztenciával kapcsolatban két fó szempontot vesz figyelembe az értékelési keret: a használat és az észlelt fontosság összhangját (azt hasznáják-e, s használják-e azt, amit fontosnak/hasznosnak tartanak), valamint a stratégiához, illetve a kitúzött célokhoz való kapcsolódást (leképezik-e a célokat a használt eszközök, s van-e visszacsatolás)

$\mathrm{Az}$ észlelt fontosság (hasznosság) és a használa összhangja a nemzetközi irodalomból ismert „túlme rés”, illetve „alulmérés” fogalmak alapján értékelhetô. A fontosnak tartott, de nem mért jellemzók esetében alulmérésról vagy mérési „résről”, míg a kevéssé fontosnak tartott, de figyelemmel kísért mutatók esetébe túlmérésról vagy hamis jelzésról" szokás beszélni (Dixon et al., 1990; Schmenner - Vollman, 1994; Schmenner, 1997). ${ }^{5}$

A stratégiához, illetve a kitúzött célokhoz való kapcsolódást tekintve a megfogalmazott célok és a rendszeresen figyelt mutatók összhangjára érdemes figyelni. (Például a fogyasztói elégedettség növelését célu kitúzố vállalatok használják-e a fogyasztói elégedettség mutatószámait, figyelik-e a reklamációk számát, a hibátlan rendelésteljesítés arányát, illetve más ehhez kapcsolódó mutatót?)

4. A döntéstámogatás, az értékteremtés támogatása: Az elóbbi jellemző́k figyelembevételével azértékteremtő folyamatokat támogató teljesítménymérési gyakorlat (1) döntéstámogatás-orientált, (2) mind tartalomba mind a felhasznált információkban több szempontú

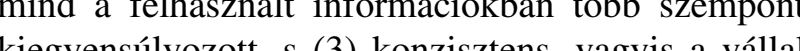

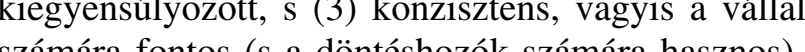
stratégiai célokat támogató információkat tartalmaz.

\section{A kutatás háttere és a minta jellemzói}

Az elemzések a Budapesti Corvinus Egyetem Vállalatgazdaságtan Intézete által vezetett ,,Versenybe a világgal" kutatási program 2009. évi felméréséne adataira - illetve, ahol ez a lehetôség adott, a kutatás három korábbi (1996., 1999. és 2004. évi) felmérésének eredményeire - épülnek. Hasonlóan a Versenyképesség-kutatás elốzó három felméréséhez, 2009-ben a vá- laszadó 300 vállalat egy-egy felső vezetôje, pénzügyi, kereskedelmi/marketing és termelési területen dolgozó vezetôje tôltôtt ki egy-egy terjedelmes (összességében toobb száz oldalas) kérdooivet, mely a vállalati múködés ês a gazdasági környezet számos területét átfogja.

A Versenyképesség-kutatások sorozatában elóször a 2004. évi felméréshez kapcsolódóan fogalmaztunk meg néhány vállalati jellemzốt, melyek alapján csoportokat képeztünk azzal a céllal, hogy ezeket minden kutató egységes, a közösen elfogadott értelmezés szerin használason a a elemzesci soŕn (erról lásd Wimmer C jektív jektív, mérhetó vagy egyértelmúen besorolható szempontokra épül (pl. vállalatméret, domináns tulajdonos, agazati hovatartozás, tevékenység diverzifikáltsága), míg mások a válalatvezetôk céljaihoz kapcsolódnak (piaci célok), illetve véleményükön alapulnak (pl. a változásokhoz való viszony, a vállalati teljesítmény megítélése a versenytársakhoz képest). A következő́kben e kiválasztott jellemzók alapján a minta néhány fố jellemzójét foglaljuk össze.

A 2009. évi versenyképességi felmérésben szereplố vállalatok többsége - a létszám és az árbevétel, illetve az eszközérték figyelembevételével - a kisvállalatok közé sorolható $(70 \%)$, közel egynegyede (23\%) a középválla toözé tatozik, s reláve kisebb ś́lya (de a sokasághoz képest így is felïlreprezentált mértékben) a sokasag a szerepeltek a nagyvallalatok. A domináns tulajdonlási forma a cégek tobb mint kétharmada esetében a hazai magántulajdon, míg a válaszadók valamivel több min 15\%-a nagyobbrészt külföldi, 10\%-a döntóen magyar állami tulajdonban van. A tulajdonosi kör és a méret kapcsolatát figyelembe véve a legnagyobb súlyt $(70 \%)$ a döntően hazai magántulajdonban lévő kis- és középvállalatok képviselik. A fố tevékenységi kört tekintve a cégek több mint $40 \%$-a a feldolgozóiparban múködik, a teljes mintában 23\%-ot képvisel a szolgáltatatás és a közösségi szolgáltatás, 19\%-ot a kereskedelem. (A részletes megoszlást lásd Csesznák - Wimmer 2011. 2011 tanulmányát)

Az elemzéshez a versenyképesség-kutatás kérdôíves felmérésének a felsővezetối, a pénzügyi, a termelési és a kereskedelmi vezetốk számára készült kérdốívei szolgáltak alapul. A vizsgált kérdések között egyszerú eldöntendố kérdések (például használnak-e bizonyos szközöket, illetve információkat) és értékelést, véle-

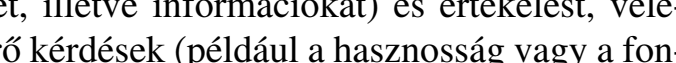
osság megítélése) is szerepelnek. Utóbbiak a jellemzó szemléletmód megismeréséhez szolgáltattak fontos adalékot, s lehetôvé tették a vallott és követett értékek osszevetését.

\section{VEZETÉSTUDOMÁNY}


A teljesítménymérési gyakorlat jellemzói a döntéstámogatás szempontjából

A következókben az 1. ábrán bemutatott elemzési keret logikáját követve összefoglaljuk a vizsgálat fóbb eredményeit.

\section{A teljesítménymérés orientációja}

\section{avagy a támogatott tevékenysége}

Az ellenốrzés és a beszámoltatás a domináns, a vállalatvezetók véleménye szerint a vállalati információs rendszerek által leginkább támogatott terület. A ,hagyományos" tervezési és ellenőrzési funkciók mellet az üzleti döntések támogatása, s a különböző vállalati tevékenységek értékelése némileg háttérbe szorul. E terïleteken a vállalati szakemberek többsége num tartjahatékonynak vállalata információs rendszerét, s e tekintetben nem történt lényeges változás a Versenykékintetben nem történt lényeges változás a
pesség-kutatás korábbi felmérései óta.

A vállalati információs rendsze

támogatása a pénzügyi vezetốk véleménye szerin (2009)

\begin{tabular}{|c|c|}
\hline Támogatott területek & $\begin{array}{c}\text { Tá- } \\
\text { moga- } \\
\text { tottság } \\
\text { átlagos } \\
\text { érték- } \\
\text { lése }\end{array}$ \\
\hline Ellenörzés, beszámoltatás & 3,89 \\
\hline Készletgazdálkodás & 3,80 \\
\hline $\begin{array}{l}\text { Termákek/termékcsoportok jövedelmezőségének } \\
\text { számitása }\end{array}$ & 3,65 \\
\hline Árképzési döntések (belső elszámoló árak kialakítása) & 3,64 \\
\hline Beruházási döntések & 3,54 \\
\hline Tervezés, tervtó́l való eltérések elemzése & 3,51 \\
\hline Tulajdonosiérték-alapú vállalatvezetés & 3,35 \\
\hline A vevốkiszolgálás költségeinek értékelése & 3,29 \\
\hline Az egyes vevók jövedelmezőśágének értékelése & 3,29 \\
\hline Egyes értékesítési formák jövedelmezőségének êrtékelése & 3,27 \\
\hline A beszállitítók teljesítményének értékelése & 3,26 \\
\hline A kiszolgálási színvonal változásának nyomon követése & 3,20 \\
\hline Elosztási csatornák ktg- és jövedelmezőség-számítása & 3,17 \\
\hline Termékösszetételre vonatkozó döntések meghozatala & 3,14 \\
\hline Termékfejlesztési döntések & 3,11 \\
\hline Társadalmilag felelốs vállalati döntéshozatal & 3,07 \\
\hline Tudásmenedzsment & 2,99 \\
\hline Tevékenységkihelyezési döntések meghozatala & 2,96 \\
\hline Venni vagy gyártani döntések meghozatala & 2,89 \\
\hline
\end{tabular}

Az 1. táblázat a vállalati információs rendszer által leginkább, illetve legkevésbé támogatott tevékenységeket mutatja a pénzügyi területért felelốs vezetók véleménye szerint. (A válaszadó pénzügyi vezetók 1-5 skálán értékelték az információs rendszert aszerint, hogy az 1 egyáltalán nem segíti az adott tevékenységet, 2 - éppen használható, 3 - elégséges, 4 - segíti a tevékenységet, 5 - igen hatékony. A táblázatban az értékelések átlaga szerepel.) Látható, hogy az átlagos értékelést tekintve az inkább támogatott tevékenységek esetében sem beszélhetünk erôs, hatékony támogatásról.

Hasonló képet mutattak a Versenyképesség-kutatás korábbi felmérésének eredményei is (ásd 2. táblázat). Közvetlen összehasonlitás nem végezhető az eltérő mintaösszetétel miatt, de az eredmények így is érdekes képet mutatnak, ha a négy, különböző idöpontban készült hasonló nagyságú (300 vállalat 4-4 felső vezetője), de eltérő összetételü mintán végzett hazai felmérés eredményeként tekintünk rájuk.

Noha a minták eltérései óvatosságra intenek a közvetlen összehasonlítások terén, látható, hogy mindhárom felmérésben úgy itélték meg a pénzügyi vezetók, hogy az az ellenőrzést és a beszámoltatást támogatja leginkább a vállalati információs rendszer a felsorolt feladatok közül. Egyértelmúnek látszik az információs rendszer döntéstámogató szerepének a növekedése szinte minden terïleten,

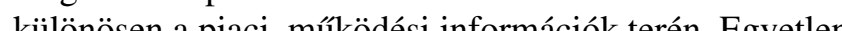
kúb́lenýg a terveźs tŕ

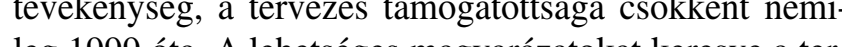
leg 19) ota. A lehetséges mán vezéssel kapcsolatos attitúd vátozása éppúgy szerepet játszhat, mint (a 2009-es felmérésnél) a válság kapcsán megjelenó bizonytalanság, ami csokkentheti a tervezhetốséget, illetve rontja lehetôségének megítélését.

A különböző funkcionális területekért felelôs vezetốk véleményét is összevetettük az információs rendszer támogató szerepével kapcsolatban (lásd 3. táblázat). 2004-ben azt tapasztaltuk, hogy egy-egy terület felelốs vezetói esetenként hatékonyabbnak, jobban használhatónak tartják a vállalati információs rendszert az általuk menedzselt területeken, mint kollégáik A 2009-es felmérésben már nem tapasztaltunk jelentós eltéréseket a külö ellok nek oka lehet a kiegyensúlyozottabb múködés, az információs rendszerek támogatásának javiása, használatának egyszerûsôdese, de a megkérdezettek körének változása is: a legutóbbi felmérésben nagyobb volt a kis- és középvállalatok aránya, $\mathrm{s}$ esetükben lehetséges, hogy kevéssé különülnek el a funkciók, illetve a kisebb szervezetekben egyszerúbb az együttmúködés és a szükséges információk megosztása a szervezeten belül. (Hasonlóképpen: a tervezés kisebb támogatottsága is összefügghet a vállalatmérettel.)
A vállalati információs rendszer támogatása a pénzügyi vezetôk véleménye szerin

(1999. 2004. és 2009. évi felmérések eredményei)

\begin{tabular}{|c|c|c|c|c|}
\hline & 1999 & 2004 & 2009 & $\begin{array}{l}\text { Támogatottság } \\
\text { változása }\end{array}$ \\
\hline Ellenôrzzés, beszámoltatás & 3,91 & 3,79 & 3,89 & hasonló \\
\hline $\begin{array}{l}\text { Termékek/termékcsoportok jövedelmezőśágének számítása } \\
\text { (1999-ben és 2004-ben: jövedelmezőség számítása) }\end{array}$ & 3,79 & 3,66 & 3,65 & hasonló \\
\hline Árképzési döntések (belső elszámoló árak kialakítása) & & 3,44 & 3,64 & hasonló \\
\hline Beruházási döntések & & 3,28 & 3,54 & hasonló \\
\hline Tervezés, tervtól való eltérések elemzése & 3,70 & 3,58 & 3,51 & kisebb \\
\hline A vevớkiszolgálás költségeinek értékelése & n. a. & 2,74 & 3,29 & nagyobb \\
\hline $\begin{array}{l}\text { Az egyes vevók jövedelmezőśégének értékelése } \\
\text { (2004-ben: vevók jövedelmezóségének értékelése) }\end{array}$ & n. a. & 2,85 & 3,29 & nagyobb \\
\hline $\begin{array}{l}\text { Az egyes értékesítési formák jövedelmezőségénéke értékelése } \\
\text { (2004-ben: értékessitési formák jövedelmezóségének êrtékelése) }\end{array}$ & n. a. & 2,93 & 3,27 & nagyobb \\
\hline $\begin{array}{l}\text { A beszállít́́́k teljesét́ményének értékelése } \\
\text { (2004-ben: beszálilítókkal kapcsolatos döntések) }\end{array}$ & 2,98 & 3,00 & 3,26 & nagyobb \\
\hline A kiszolgálási színvonal változásának nyomon követése & 2,75 & 2,54 & 3,20 & változó, nagyobb \\
\hline Elosztási csatornák költség- és jövedelmezőségének számítása & 2,41 & 2,44 & 3,17 & nagyobb \\
\hline Termékösszetételre vonatkozó döntések meghozatala & 2,98 & 2,91 & 3,14 & nagyobb \\
\hline Termékfejlesztési döntések & n. a. & 2,62 & 3,11 & nagyobb \\
\hline Tevékenységkihelyezési döntések meghozatala & 2,69 & 2,57 & 2,96 & nagyobb \\
\hline Venni vagy gyártani döntések meghozatale & 2,56 & 2.46 & 89 & nagyobb \\
\hline
\end{tabular}

3. táblázat

A vállalati információs rendszer támogató szerepe a különbözố vezetók véleménye szerint (2009)

\begin{tabular}{|c|c|c|c|c|c|}
\hline & $\begin{array}{l}\text { Felsố- } \\
\text { vezetố }\end{array}$ & $\begin{array}{l}\text { Pénzügyi } \\
\text { vezetóo }\end{array}$ & $\begin{array}{c}\text { Keres- } \\
\text { kedelmi } \\
\text { vezetó }\end{array}$ & $\begin{array}{l}\text { Termelési } \\
\text { vezetó }\end{array}$ & $\begin{array}{l}\text { Értékelések } \\
\text { átlaga }\end{array}$ \\
\hline A vállalat egésze teljjesítményének értékelése & 3,85 & 3,92 & 3,79 & 3,81 & 3,84 \\
\hline Ellenôrzés, beszámoltatás & 3,71 & 3,88 & 3,77 & 3,64 & 3,75 \\
\hline Üzleti döntések meghozatala & 3,79 & 3,68 & 3,78 & 3,66 & 3,73 \\
\hline Kommunikáció, információ megosztása a szervezeti egységek között & 3,71 & 3,61 & 3,76 & 3,69 & 3,69 \\
\hline Az egyes funkcionális területek teljessítményének értékelése & 3,67 & 3,69 & 3,59 & 3,65 & 3,65 \\
\hline Költségcsökkentési lehetősségek feltárása & 3,64 & 3,63 & 3,69 & 3,60 & 3,64 \\
\hline Tervezés & 3,73 & 3,49 & 3,67 & 3,55 & 3,61 \\
\hline Kommunikáció, információ megosztása az üzleti partnerekkel & 3,53 & 3,41 & 3,64 & 3,40 & 3,50 \\
\hline A belsố vállalati folyamatok fejlesztése & 3,49 & 3,34 & 3,56 & 3,31 & 3,43 \\
\hline A munkatársak teljesítményének értékelése & 3,46 & 3,34 & 3,47 & 3,33 & 3,40 \\
\hline A vevối elégedettség változásának nyomon követése & 3,41 & 3,31 & 3,45 & 3,23 & 3,35 \\
\hline Az üzletti partnerek teljesítményének értékelése & 3,31 & 3,31 & 3,39 & 3,31 & 3,33 \\
\hline Az egyes stratégiai partnerekkel való együttmúködés fejlesztése & 3,33 & 3,25 & 3,46 & 3,23 & 3,32 \\
\hline A munkatársak elégedettségének nyomon követése & 3,13 & 3,02 & 3,17 & 2,95 & 3,07 \\
\hline
\end{tabular}

\section{VEZETÉSTUDOMÁNY}

XLIII. ÉVF. 2012. 7-8. SZÁM / ISSN 0133-0179 
2009-ben gyakorlatilag minden vizsgált tevékenység támogatottságának megítélése jobb, mint 2004-be volt. A tevékenységek támogatottságának a sorrendje nem sokat változott: a listavezetók a vállalati szintú teljesítményértékelés és az ellenőrzés, beszámoltatás, míg kevésbé támogatott területek között az érintettekkel kapcsolatos információk találhatók. A sorrendben leginkább a tervezés támogatottsága szorult hátrébb (noha az értékelés itt is jobb, mint az öt évvel korábbi felmérésben) A leginkább támogatott tevékenységek értékelését tekinve nincs jelentốs változás a megítélésben, míg a lista második felében szereplô tevékenységek esetében a frissebfelmérésben jelentôsen jobbn f́ćlték á́m g a rissebb felmérésben jelentốsen jobbnak ielték a támogatottság a vezetôk (például a munkatársakkal, vevőkkel, üzle partnerekrel kapcsola ins interciókat tekintve). Szembetưnô, hogy a leginkább támogatott tevékenységekné sem éri el az ertekelések átlaga a négyes átlagot az otös skálán: a listavezetó tevékenységek értékelése átlagosan 3,7-3,8 körüli. A legkevésbé támogatottnak észlelt tevékenységeknél jelentôsen javult a megítélés: 2004-ben ha esetben nem érte el a hármas átlagot, míg a legújabb felmérésben minden esetben meghaladja azt.

\section{Kiegyensúlyozottság az információforrások és} a teljesítménymutatók használatában

A döntéstámogatás szempontiából fontos, hogy mi-

lyen jellegú, mennyire sokoldalú információk állnak

a döntéshozók rendelkezésére. A különböző típusú teljesítményjellemzók figyelembevétele, s különbözô forrásokbôl származo információk felhasználása kiegyensúlyozottabb, átfogóbb képet nyújt, s segítheti a döntéshozókat a kritikus tényezók megtalálásában. Kutatásunkban a pénzügyi vezetốket és a termelési vezetốket is megkértük, hogy értékeljenek egy-egy teljesítménymutatókat és elemzési eszközöket tartalmazó listát: egyrészt nyilatkozzanak, hogy használják-e a felsorolt eszközöket, másrészt értékeljék azokat hasznossásuk, illetve fontosságuk szerint. A válaszok alapján nemesak a legelterjedtebb, illetve leginḱbb (vapy jan nemcsak a legelterjedtebb, illetve leginkább (vagy est eszközökről kaphatunk képet, hanem megvizsgálhatjuk a vállalati gyakorlat övetkezetességét, konzisztenciáját is.

A 4. táblázat a legtöbb válaszadó által használt eszközöket tartalmazza, az elterjedtség szerinti csökkenó sorrendben. A táblázat utolsó oszlopa a mutatók/módszerek jellegére utal (pénzügyi, finanszírozási, múködési stb.). Az 5. táblázat a korábbi felmérések eredményeit is felhasználva készült (ismét hangsúlyozva, hogy a minták nem azonosak)

A 4. táblázatból látható, hogy a pénzügyi kimutatásokhoz kapcsolódó módszerek a leginkább elterjedtek: a 2009 évi adatok szerint a válaszadók közelitöleg négyötöde elemez pénzïgyi mutatószám cash flow-kimutatást. A piaci és a múködési jellemzők

4. táblázat

Alegelterjedtebb módszere

(2009)

\begin{tabular}{|c|c|c|c|}
\hline & Használat & Fontosság átl. értékelése & Terület \\
\hline Cash flow-kimutatás & $82,9 \%$ & 3,91 & pénzügy \\
\hline Pénzügyi mutatószámok elemzése & $79,5 \%$ & 4,04 & pénzügy \\
\hline Fix/változó költségek elkülönítése & $73,5 \%$ & 4,00 & pénzügy, költségek \\
\hline Vevối reklamációk száma & $72,9 \%$ & 4,21 & múködés, vevókiszolgálás \\
\hline Vásárlói elégedettség & $65,2 \%$ & 4,40 & múködés, vevókiszolgálás \\
\hline Vevốk forgási idejének elemzése & $64,7 \%$ & 3,91 & pénzügy, finanszírozás \\
\hline Termék/szolgáltatás minősége & $64,7 \%$ & 4,29 & múködés, minőség \\
\hline Készletforgási mutatók elemzése & $62,0 \%$ & 3,71 & múködés, finanszírozás \\
\hline Rendelésteljesítés pontossága & $61,8 \%$ & 4,22 & múködés, vevốkiszolgálás \\
\hline Termelékenység & $60,1 \%$ & 4,24 & múködés, gazdaságosság \\
\hline Reklamációkezelés gyorsasága & $56,0 \%$ & 4,12 & múködés, vevókiszolgálás \\
\hline Tevékenységalapú költségszámítás & $55,4 \%$ & 3,82 & pénzügy, költségek \\
\hline Szállítók forgási idejének elemzése & $54,9 \%$ & 3,79 & pénzügy, finanszírozás \\
\hline Cash flow-alapú mutatók elemzése & $54,1 \%$ & 3,83 & pénzügy \\
\hline Fedezetipont-számítás & $52,9 \%$ & 3,86 & pénzügy, költségek \\
\hline Rendelésteljessités idôtartama (gyorsaság) & $52,4 \%$ & 4,00 & múködés, vevốkiszolgálás \\
\hline Költségérzékenységi vizsgálatok & $52,1 \%$ & 3,85 & pénzügy, költségek \\
\hline
\end{tabular}

VEZETÉSTUDOMÁNY közül a vevői reklamációk számának mérése a leginkább elterjedt, a válaszadók több mint $70 \%$-a figyeli, míg a vevői elégedettség és a termékek/szolgáltatáso minőségének mérése valamivel elmarad a kétharmados említettségtől. A korábbi felmérések szerint is meghatározó volt a pénzügyi teljesítménymérési eszközö használata, s elterjedtségük nem mutat jelentős eltéréseket a különbözö felmérések szerint. Ennél változatosabb a működéshez és a piaci jellemzökhöz kapcsolódó mutatók használatáról kapott kép (l. 5. táblázat).

Néhány mutató használatának változása (1996, 1999, 2004, 2009)

\begin{tabular}{|l|c|c|c|c|}
\hline & $\mathbf{1 9 9 6}$ & $\mathbf{1 9 9 9}$ & $\mathbf{2 0 0 4}$ & $\mathbf{2 0 0 9}$ \\
\hline Cash flow-kimutatás & $76,9 \%$ & $79,7 \%$ & $85,8 \%$ & $82,9 \%$ \\
\hline Pénzügyi mutatószámok elemzése & & & $88,1 \%$ & $79,5 \%$ \\
\hline Fix/változó költségek elkülönítése & $72,6 \%$ & $74,0 \%$ & $74,5 \%$ & $73,5 \%$ \\
\hline Vevói reklamácí́k száma & & $73,9 \%$ & $77,9 \%$ & $72,9 \%$ \\
\hline Vásárlói elégedettség & $31,7 \%$ & $48,7 \%$ & $65,2 \%$ & $65,2 \%$ \\
\hline Termék/szolgáltatás minő́śége & $52,0 \%$ & $81,7 \%$ & $77,2 \%$ & $64,7 \%$ \\
\hline Készletforgási mutaták elemzźse & $76,9 \%$ & $66,3 \%$ & $66,8 \%$ & $62,0 \%$ \\
\hline Rendelésteljessítés pontossága & & $67,7 \%$ & $61,2 \%$ & $61,8 \%$ \\
\hline Termelékenysé́ & $52,6 \%$ & $72,3 \%$ & $77,7 \%$ & $60,1 \%$ \\
\hline
\end{tabular}

Az 1996 óta folytatott felméréssorozat eredményeit vizsgálva a következó tendenciák figyelhetók meg: it vizsgálva a következố tendenciák figyelhetốk meg: az elsố felmérés idején a pénzügyi, főleg a finansz rozáshoz kapcsolódó mutatók, módszerek használat jellemezte a vállalati gyakorlatot, s a múködéshez kapcsolódó teljesítménymutatók közül csak a készletmutatók, -elemzési módszerek szerepelnek a legelterjedteb módszerek listáján. A hagyományos, pénzügyi és kölségalapú mutatók korábbi dominanciájában vélhetőe nagy szerepe volt a vállalatokra nehezedô finanszírozási nyomásnak. Az sem elhanyagolható, hogy ezek az információk könnyebben elérhetóek, elóállíthatóak a - törvényi elóírások, illetve a tulajdonosok elvá rásai miatt - kötelezố kimutatások felhasználásáva A három évvel késóbo ki knón A három évvel későbbi eredmények már jelezték, hogy a minôség is kiemelt versenytényezővé vált. A késztermék minőségének mérését tartották a legfontosab nak a válaszadók (átlagos értékelés 4,8), s több mi 80 szazzalekuk használt is erre valamilyen mérôszámo ami az elsố felmérés során tapasztalt 50 százalékot alig meghaladó arányhoz képest jelentôs előrrelépést jelentett. A 2004. évi felmérés eredményei a korábbi tapas talatokat is figyelembe véve sokkal kiegyensúlyozo tabb képet mutattak a vállalati gyakorlatról, melyben - a továbbra is meghatározó pénzügyi teljesítményjel- lemző́k követése mellett - a minőség és a vevôkiszolgálás elemei is egyre hangsúlyosabban jelentek meg. A200-es felmeres is azt jelzi, hogy a minóség és a vevó elégedettség mutatói stabil helyet vívtak ki maguknak a legelterjedtebb teljesítménymutatók között. Ugyanakkor figyelemfelkeltó, hogy a legújabb felmérésben a használók aránya általában kisebb: felmerül a kérdés, hogy ez mennyiben a válaszadók körének (kisvállalatok nagyobb súlya) következménye, vagy a nem pénzügyi teljesítménymutatókra irányuló figyelem csökkenésére

utal a pénzügyi nehézségek között. A mérhetớsé́ az az információnoz jutás mérhetôség, az információhoz jutâs nehézsége is fontos befolyásoló tényezó a teljesítménymérés gyakorlatát tekintve. Ezt láthattuk már a 2004. évi adatokbol is, miszerint a könnyebben gyưjthetô vevôi reklamációk száma mutatót bár kevésbé értékelték fontosnak, mint a vásárlók elégedettségét $(4,15$ vs 4,5 ), de többen használták ( $78 \%$ vs. $65 \%)$. A 2009. évi válaszadóknál is hasonló a kép: a reklamációk számának fontosságát átlagosan 4,21, a vásárlói elégedettségét 4,4-re értékelték, míg a használók köre 72,9\%, illetve $65,2 \%$. $\mathrm{Az}$ információk felhasználását megjelenítési módját jellemzi, hogy a kontrollingielentés (lasd 6. tóblázat) tovább is a

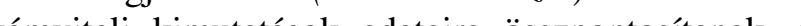

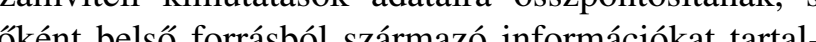
maznak. Az értékesítés mennyiségi máción öltség- ́s jövékesités mennyiségi adatai mellett a költség- és jövedelmezőségi elemzések szerepeltetése is elterjedt. Előrelépés észlelhetô a külső információk becsatornázásában, például a vevốkkel és a beszállítókkal kapcsolatos információk használatáról jelentősen nagyobb arányban számoltak be, mint korábban.

A korábbi felmérések tapasztalataival összevetve hasonló a kép, mint az információs rendszer által nyújtott támogatásnál: a tervhez viszonyított teljesítmény alakulása, valamint a termelékenység alakuǴsa a 2009-es felmérés szerint kevésbé jelenik mulo a kon koráb(a) tána éto felmérés válaszadói szerint, noha a fontosságuk megitelése csak kismértékben csökkent. kontrollingjelentésekben kevésbé megjelenő területek között növekszenek a vevökiszolgálás költségei, valamint jövedelmezösége fontosságának és hasznosságának megítélése.

A kontrollingjelentések legföbb információforrását továbbra is a belső vállalati információk jelentik, elsossorban a pénzügyi adatok, ugyanakkor a válaszadók

\section{VEZETÉSTUDOMÁNY}


A kontrollingielentések tartalma (2009)

\begin{tabular}{|c|c|c|}
\hline & Használat & Átlagos értékelés \\
\hline A számviteli kimutatásokból származó adatok & $97,2 \%$ & 4,45 \\
\hline Pénzügyi mutatószámok & $91,7 \%$ & 4,36 \\
\hline Költségelemzések (pl. fedezetelemzés) & $86,9 \%$ & 4,35 \\
\hline Az értékessítés alakulására vonatkozó mennyiségi információk & $80,4 \%$ & 4,39 \\
\hline A termékek jövedelmezőségére vonatkozó információk & $75,0 \%$ & 4,30 \\
\hline A tervhez (normához) viszonyított teljesítmény alakulása & $71,4 \%$ & 4,07 \\
\hline Az alkalmazottak teljesítményére vonatkozó információk & $63,0 \%$ & 3,97 \\
\hline A vevốk elégedettségének alakulása & $58,2 \%$ & 4,00 \\
\hline A vállalat termékeinek (szolgáltatásainak) minőségére vonatkozó információk & $55,0 \%$ & 4,01 \\
\hline A rendelésteljesítés pontossága & $51,4 \%$ & 3,81 \\
\hline Az értékesítési csatornák költségeire vonatkozó információk & $50,9 \%$ & 3,82 \\
\hline Az értékesítési csatornák jövedelmezőségére vonatkozó információk & $50,2 \%$ & 3,89 \\
\hline Az erớforrások kihasználtságának alakulása & $49,5 \%$ & 3,83 \\
\hline A beszállitíók teljesítményére vonatkozó információk & $49,3 \%$ & 3,70 \\
\hline A vevốkiszolgálás költségeire vonatkozó információk & $48,4 \%$ & 3,92 \\
\hline A versenytársak helyzetére vonatkozó információk & $43,4 \%$ & 3,70 \\
\hline Elốrejelzés a külsố környezet várható alakulásáról & $41,4 \%$ & 3,76 \\
\hline A rendelésteljessités rugalmassága & $38,4 \%$ & 3,65 \\
\hline Az egyes vevớk kiszolgálásának jövedelmezőségére vonatkozó információk & $38,4 \%$ & 3,67 \\
\hline A termelékenység alakulása, az input és az output viszonya & $38,3 \%$ & 3,74 \\
\hline A kiszolgálási idó alakulása & $36,0 \%$ & 3,61 \\
\hline A külsố környezet tényleges és tervezett alakulásának elterése & $34,4 \%$ & 3,66 \\
\hline A vállalatit tudásvagyon részeinek változása & $22,9 \%$ & 3,40 \\
\hline
\end{tabular}

közel háromnegyede esetében a vállalati információs hasznosnak tartott eszközök sorrendje nem feltétlenül rendszer nem pénzügyi adatai is megjelennek. A külső azonos a legelterjedtebbekével. A versenyképesség információforrások, illetve a (szubjektív) vélemények felméréseink tendenciáját tekintve ugyanakkor növekbecsatornázása e jelentésekbe visszafogottabb, bár há- vő összhangot jeleznek: 2004-re jelentôsen csökkent a rom érintett csoport (vevők, beszállítók, munkatársak) korábban (fóként az 1996-os felmérésünknél) tapaszesetében is a válaszadók fele-kétharmada nyilatkozott talható ellentmondás, miszerint a múködéshez kapcsoúgy, hogy használ ilyen információforrásokat a jelen- lódó mutatókat fontosabbnak tartották, míg a pénzügyi tésekhez.

\section{Konzisztencia, avagy megfelelés a belsó}

\section{elvárásoknak}

A következő́kben a teljesítménymérési gyakorlat konzisztenciáját értékeljük, annak alapján, hogy menynyire felel meg a vállalatok által képviselt értékeknek (különböző tényezók fontosságának, hasznosságának megítélése) és a megfogalmazott céloknak.

A 7. táblázat a leghasznosabbnak ítélt teljesítménymérési módszereket, mutatókat tartalmazza. A legelterjedtebb módszerek élmezónyét tartalmazó 4. táblăzattal összevetve látható, hogy a leginkább fontosnak, elemzési eszközöket jóval szélesebb körben használták a vállalatok.

Összességében az elterjedtebb módszereket általában hasznosabbnak tartják a vállalatvezetők, mint a kevéssé elterjedteket (másként fogalmazva: a hasznosabbnak ítélteket többen használják), viszonylagos onzisztencia uralkodik tehát.

Megvizsgáltuk, hogy azonosítható-e a szakirodalomban „alulmérés”(vagy mérési rés), illetve,,túlmérés” (vagy hamis jelzés) néven ismert jelenségek: fontosnak tartott, de nem mért jellemzők esetében alulmérésről, míg a kevéssé fontosnak tartott, de figyelemmel kísért mutatók esetében tulméresrol beszelhetünk (Dixon et

VEZETÉSTUDOMÁNY

al., 1990; Schmenner - Vollman, 1994; Schmenner, képest. Relatív túlmérésról, illetve alulmérésról beszél1997). A Versenyképesség-kutatás korábbi felmérései hetünk azon módszerek esetében, melyek kívül esnek a során a klasszikus pénzügyi információk (pl. pénzügyi mintában tapasztalt használat-hasznosság kapcsolatok mutatószámok, cash flow) esetében inkább túlmérést, sávján: más, hasonlóan fontosnak tartott módszerekmíg a müködési folyamatokhoz, vevőkiszolgáláshoz, hez képest jóval elterjedtebbek, illetve éppen fordítva, vevői elégedettséghez kapcsolódóan inkább alulmérést sokkal kevesebben használják őket. Másik oldalról azonosítottunk (Wimmer, 2000, 2004). A tendenciákat az elózetes (kutatói) elvárások, szakmai tapasztalatok tekintve az alulmérés csökkent, a leginkább fontosnak alapján (némileg szubjektív módon) is minősíthetố az tartott mutatók (pl. termék/szolgáltatás minősége, ve- alulmérés vagy túlmérés (pl. bizonyos átlagos értékelés vői elégedettség) mérésének növekvő elterjedtségét ta- felett egy meghatározott elterjedtségnél kisebb hasznápasztalhattuk a kutatások sorában.

lat alulmérésként definiálható). A két közelítés eltéró következtetésekkel is járhat, lehetséges, hogy egy válrozhatjuk a vállalati gyakorlatban (a vizsgált mintában) lalati körben ,általános" az alulmérés, s így ami a (kumegjelenő szokások alapján, az általános „trendhez” tatói) elvárás alapján alulmérésként lenne értékelhető,

7. táblázat

A leghasznosabbnak ítélt módszerek (2009)

\begin{tabular}{|c|c|c|c|}
\hline & Használat & $\begin{array}{l}\text { Fontosság átlagos } \\
\text { értékelése }\end{array}$ & Terület \\
\hline Vásárlói elégedettség & $65,2 \%$ & 4,40 & múködés, vevốkiszolgálás \\
\hline Termék/szolgáltatás minősége & $64,7 \%$ & 4,29 & múködés, minőség \\
\hline Termelékenység & $60,1 \%$ & 4,24 & múködés, gazdaságosság \\
\hline Rendelésteljesítés pontossága & $61,8 \%$ & 4,22 & múködés, vevốkiszolgálás \\
\hline Vevői reklamációk száma & $72,9 \%$ & 4,21 & múködés, vevốkiszolgálás \\
\hline Reklamációkezelés gyorsasága & $56,0 \%$ & 4,12 & múködés, vevókiszolgálás \\
\hline Pénzügyi mutatószámok elemzése & $79,5 \%$ & 4,04 & pénzügy \\
\hline Rendelésteljessítés idôtartama (gyorsaság) & $52,4 \%$ & 4,00 & múködés, vevốkiszolgálás \\
\hline Fix/változó költségek elkülönítése & $73,5 \%$ & 4,00 & pénzügy, költségek \\
\hline Vevók forgási idejének elemzése & $64,7 \%$ & 3,91 & pénzügy, finanszírozás \\
\hline Cash flow-kimutatás & $82,9 \%$ & 3,91 & pénzügy \\
\hline Vásárlói lojalitás & $35,9 \%$ & 3,87 & múködés, vevő́kiszolgálás \\
\hline Fedezetipont-számítás & $52,9 \%$ & 3,86 & pénzügy, költségek \\
\hline Költségérzékenységi vizsgálatok & $52,1 \%$ & 3,85 & pénzügy, költségek \\
\hline Cash flow-alapú mutatók elemzése & $54,1 \%$ & 3,83 & pénzügy \\
\hline Vállalati tókeköltség elemzése beruházási döntéseknél & $48,0 \%$ & 3,82 & pénzïgy, befektetés \\
\hline Tevékenység-alapú költségszámítás & $55,4 \%$ & 3,82 & pénzügy, költségek \\
\hline Szállítók forgási idejének elemzése & $54,9 \%$ & 3,79 & pénzügy, finanszírozás \\
\hline Alkalmazottak elégedettsége & $45,0 \%$ & 3,78 & Múködés, munkatársak \\
\hline Készletforgási mutatók elemzése & $62,0 \%$ & 3,71 & múködés, finanszírozás \\
\hline Alkalmazotti javaslatok száma & $41,7 \%$ & 3,68 & Múködés, munkatársak \\
\hline A vállalat piaci értékére vonatkozó mutatók elemzése & $39,3 \%$ & 3,64 & pénzügy, befektetés \\
\hline Célköltségszámítás & $39,3 \%$ & 3,58 & pénzügy, költségek \\
\hline $\begin{array}{l}\text { Gazdasági hozzáadott érték (EVA) mutató, vagy más } \\
\text { maradványjellegú mutató elemzése }\end{array}$ & $28,0 \%$ & 3,40 & pénzügy, befektetés \\
\hline Költségalapú szállitóértékelési módszerek & $29,0 \%$ & 3,38 & pénzügy, költségek \\
\hline Pénzkonverziós ciklus elemzése & $29,8 \%$ & 3,35 & pénzügy, finanszírozás \\
\hline Balanced Scorecard mutatószám rendszer & $22,1 \%$ & 3,24 & több szempontú teljesítmény \\
\hline
\end{tabular}

\section{VEZETÉSTUDOMÁNY}

XLIII. ÉVF. 2012. 7-8. SZÁM / ISSN 0133-0179 
Észlelt fontosságukhoz viszonyítva

relatív alulméréssel vagy túlméréssel jellemezhetô mutatók/módszerek

(példák, 2009) (használók aránya, hasznosság értékelése)

\begin{tabular}{|l|l|}
\hline \multicolumn{1}{|c|}{ Relatív alulmérés } & \multicolumn{1}{c|}{ Relatív túlmérés } \\
\hline Vásárlói lojalitás $(35,9 \%, 3,87)$ & Készletforgási mutató $(62 \% ; 3,71)$ \\
\hline Rendelésteljesítés időtartama, gyorsasága $(52,4 \% ; 4,00)$ & Cash flow-kimutatás $(82,9 \% ; 3,91)$ \\
\hline Vásárlói elégedettség $(65,2 \% ; 4,4)$ & \\
\hline Termék/szolgáltatás minősége $(64,7 \% ; 4,29)$ & \\
\hline
\end{tabular}

az adott mintában a válaszokból következó gyakorlatot tekintve viszonyítási alapnak, már (relatív) túlmérésként értékelődik.

A 8. táblázatban néhány olyan mutatót emeltünk ki, melyek a fontosság alapján elfoglalt helyükhöz képest kevéssé mérnek (relatív alulmérés), illetve viszonylag elterjedtek (relatív túlmérés).

A legszélesebb körben használt tíz eszköz (60-83\% között a felhasználók aránya) közül a készletforgás mutatók elemzése, a cash flow-kimutatás és a vevök forgási idejének elemzése elterjedtségéhez képest viszonylag hátrébb került a hasznossági rangsorban. Érdekes a hasonlóan elterjedt módszerek értékelése is: a válaszadók valamivel több mint fele ( $50-55 \%$-a) nyilatkozott úgy, hogy méri a reklamációkezelés gyorsaságát (a fontosság átlagos értékelése: 4,12), a rendelésteljośtés időtartamát $(4,00)$, elemez cash flow-apú mele-

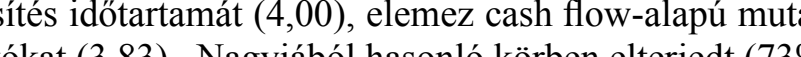
körüli) a vevői reklamációk számának követése és fix/változó költségek elemzése, előbbi hasznosságának értékelése azonban jobb $(4,21$ vs. 4,00$)$. A közvetlen értékelést ugyanakkor nehezíti, hogy a módszerek két csoportját nem ugyanazok a személyek (pénzügyi, illetve termelési vezetők) értékelték.

Az egyes módszerek hasznosságának, fontosságának a felismerése is fontos értékteremtő tényezö lehet, mely befolyásolja a vállalati szemléletmódot, döntéseket, akkor is, ha nem minden esetben kapcsolódik hozzá formális mérés. Ez különösen érvényes lehet 2009-es felmérés eredményeire, ahol nagyobb a kis- ćs középvállalatok aránya mint korábban így elképzelhetö, hogy egyes kiemelt teljesítményjellemzök értéépül be a döntéshozatalba (ami nagyobb szervezetek esül be a döntéshozatalba (ami nagyobb

esetében már nehezébén megvalósitható.)
A teljesítménymérés konzisztenciáját tekintve a tenA teljesitménymérés konzisztenciajat tekintve a tendenciák egyértelmüen a következetesség térnyerését jelzik a 15 évvel ezelötti első felmérés óta. Ugyanakkor az is látható, hogy a fontosság felismerése egy-egy tényező esetében nem mindig jár a használat elterjedésével, aminek módszertani, illetve költségbeli ok is lehetnek. Az 1996. évi első felmérés idején a legnagyobb ellentmondás a használat és az értékelés között a vásárlói elégedettség, a késztermékminőség és a termelékenység esetében volt megfigyelhetö: bár a vállalatok közel fele (a vásárlói elégedettség esetében kétharmada) nem alkalmazta ezeket a teljesítménymutatókat, a nem használók is igen fontosnak tartották fontosságukat. A minőség esetében már 1999-re megszunt ez a ress, s jelentosen nőtt a késztermék minőségét rendszeresen figyeló vállalatok aranya. Továbbra is kritikus pontnak szamitott azonban a vevooi elégedettség mérése. Az 1999. évi felmérésben az alulmérés föként a vevőkiszolgáláshoz kapcsolódó mutatókat jellemezte. A legnagyobb rés a vásárlói elégedettség esetében volt tapasztalható, melyet a válaszadók kevesebb min fele mért de a mutatót nem használók is igen fontos-

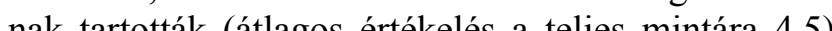
A 2004 évi felméćs en válés a tél jóva

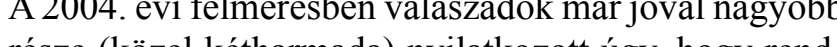
tesze (közel ketharmada) nyilatkozott ugy, hogy rendszz"resén fisyeli a vevoi elégedettseget, ami jelentős elorelépést jelent, bar az észlelt fontossághoz képest $(4,5)$ továbbra sem tekinthetö túlzottan magas aránynak. Mindenesetre 1996 óta nött a konzisztencia a már akkor is fontosnak tartott minöseghez kapcsolódó jellemzők követése, s 1999 óta a vásárlói elégedettség követése tekintetében. Az újabb „rések” a teljesítménymérési gyakorlatban, az alulmérés az eddig kevéssé figyelemmel kísért versenytényezőhöz, az időhöz kapcsolódnak. A rendelésteljesítés pontosságát, illetve idötartamát fontosnak tartják a válaszadók, de mérésük nemáltános. További viszonylag elhanyagolt de fon-

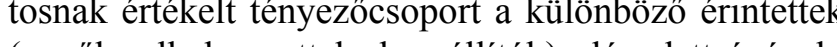
(vevook, alkaltazotlak, beszallitok) sítményének követése.

A különböző mutatók és eszközök észlelt hasznossága és használata közötti inkonzisztencia több okkal is magyarázható: A túlmérés, a szélesebb körú elterjedtség következhet a hagyományokból, a megszokásból géből, a mérés alacsony költségéból is a vállalati veezeket, s 85-90 százalékuk 4 vagy 5 pontra értékelte to illetve az információk viszonylag egyszerú elérhetősé- zetók szómára viszonylag kevésbé fontos módszerek esetében. (Ezt láthattuk a vevói elégedettség mérése és a reklamációk számának a rögzítése esetében is A kevéssé értékelt fontosság/hasznosság azt is jelezheti, hogy a válaszadók nem tudják megfelelően hasznosítani az adott eszközöket, nem használják ki az információs rendszerben lévô lehetóségeket, nem értik és értékelik az egyes módszerek hasznosságát. Mind az elôzố, mind a legfrissebb felmérés szerint viszonylagos túlmérés jellemzi a cash flow-kimutás, gos túl illetve a kés jellerában a készletszinek) vizsenis viszonylag szeles köben eltjedtek, ugyanakkor vezetók egy része viszonylag kevésbé tartja hasznosnak ezeket. Mindez vélhetốen nem ezen eszközök alkalmatlanságát jelzi, hanem sokkal inkább a felhasználás, a döntéstámogató hasznosítás nehézségeit, mely tartalmi és formai problémákra, értelmezési és kommunikációs nehézségekre egyaránt utalhat.

$\mathrm{Az}$ alulmérés, illetve túlmérés értékeléséhez érdemes arra is figyelemmel lennünk, hogy az egyes eszközöket használó és nem használó vállalatok értékelése az adott esz-

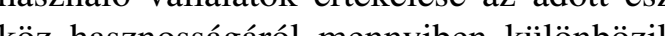
A termelési vezetôk A tên teljesítménymutatók/eszközök esetében jóva kisebb a használó és nem használó vállalatvezetók értékelêse koözotti különbség, mint pénzügyi vezetơk által értékelt, jellemzóen pénzügyi/számvitel/költségelemzési eszközök esetében. Az átlagos elterés ebben a körben 0,86 az $1-5$ skálán, míg a pénzügyi vezetớk által értékelt pénzügyi eszközök esetében ennek csaknem kétszerese, 1,54. Az egyes módszereket használók mindkét csoportban átlagosan 4 pont feletti értékelést adtak a különbözố eszközök hasznosśágáról: a pénzügyi vezetók 17, döntôn pénziigyi és këltségalapú módszert ér

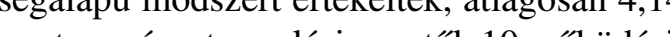

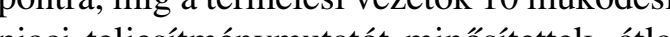

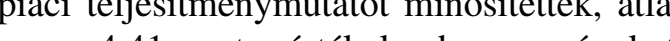
gosan 4,41 pontra ertékelve hasznosságukat Az egyes módszercket nem használok êtékelése a termelési vezetốk esetében 3,54 pont míg a pénzügyi módszereknél csak 2,62 volt (lásd 2. és 3. ábra)

Kétmintás próbák segítségével vizsgáltunk különböző módszereket: attól függóen, hogy használják-e vagy sem, mennyire tartották hasznosnak a vállalatvezetốk. Valamennyi módszer, mutatószám esetében a megfelelô kétmintás t-próbát használva szignifikáns különbséget találtunk: az egyes módszereket használók hasznosabbnak is értékelik azokat (4. ábra).

A módszerek hasznosságának értékelése az azokat használók és nem használók körében (pénzügyi vezetők, 2009)

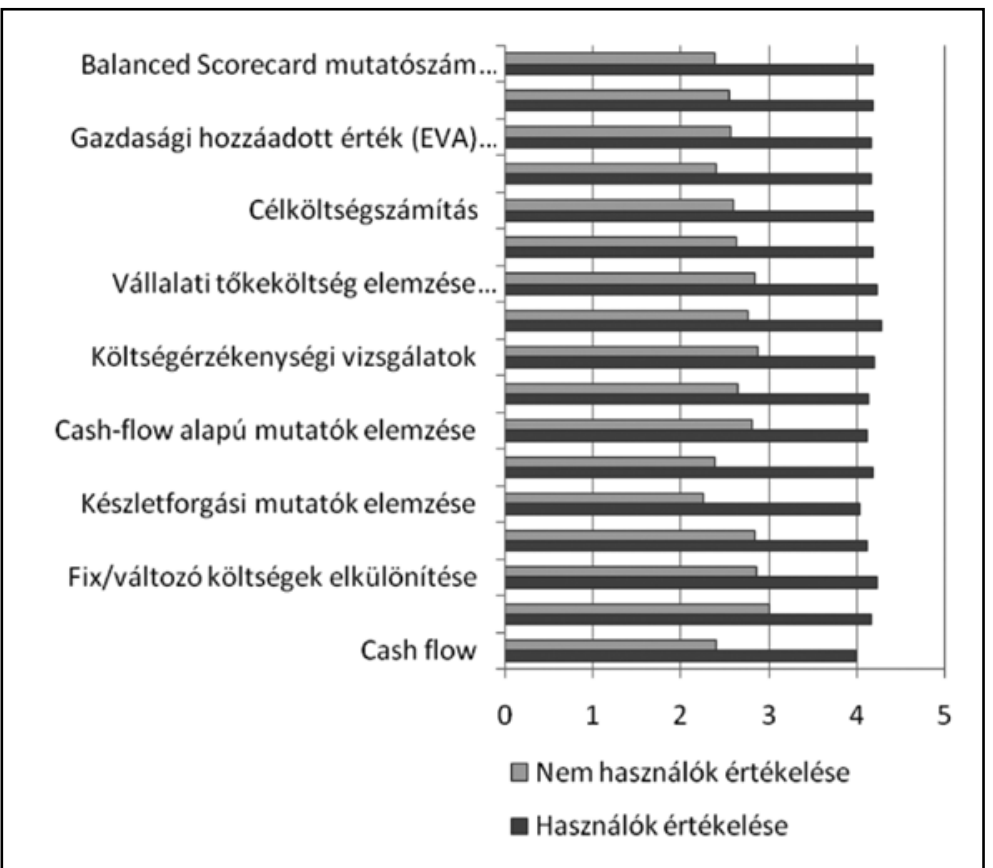

A módszerek hasznosságának értékelése azokat használók és nem használók körében (termelési vezetốk, 2009)

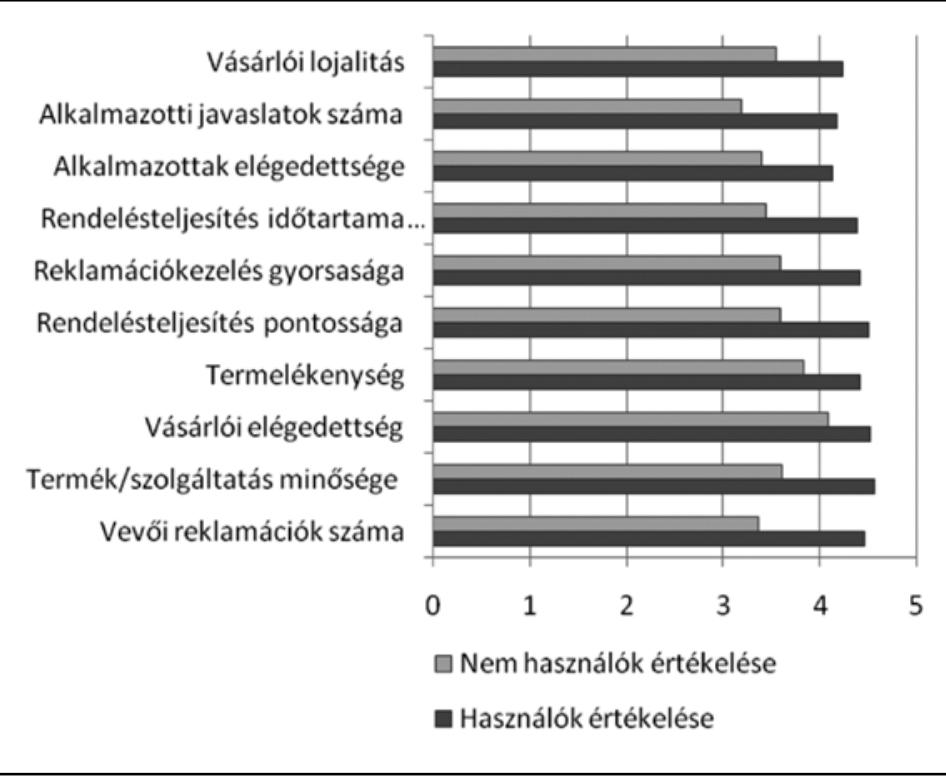


A módszerek hasznosságának értékelése az azokat használók és nem használók körében (termelési vezetők, 2009)

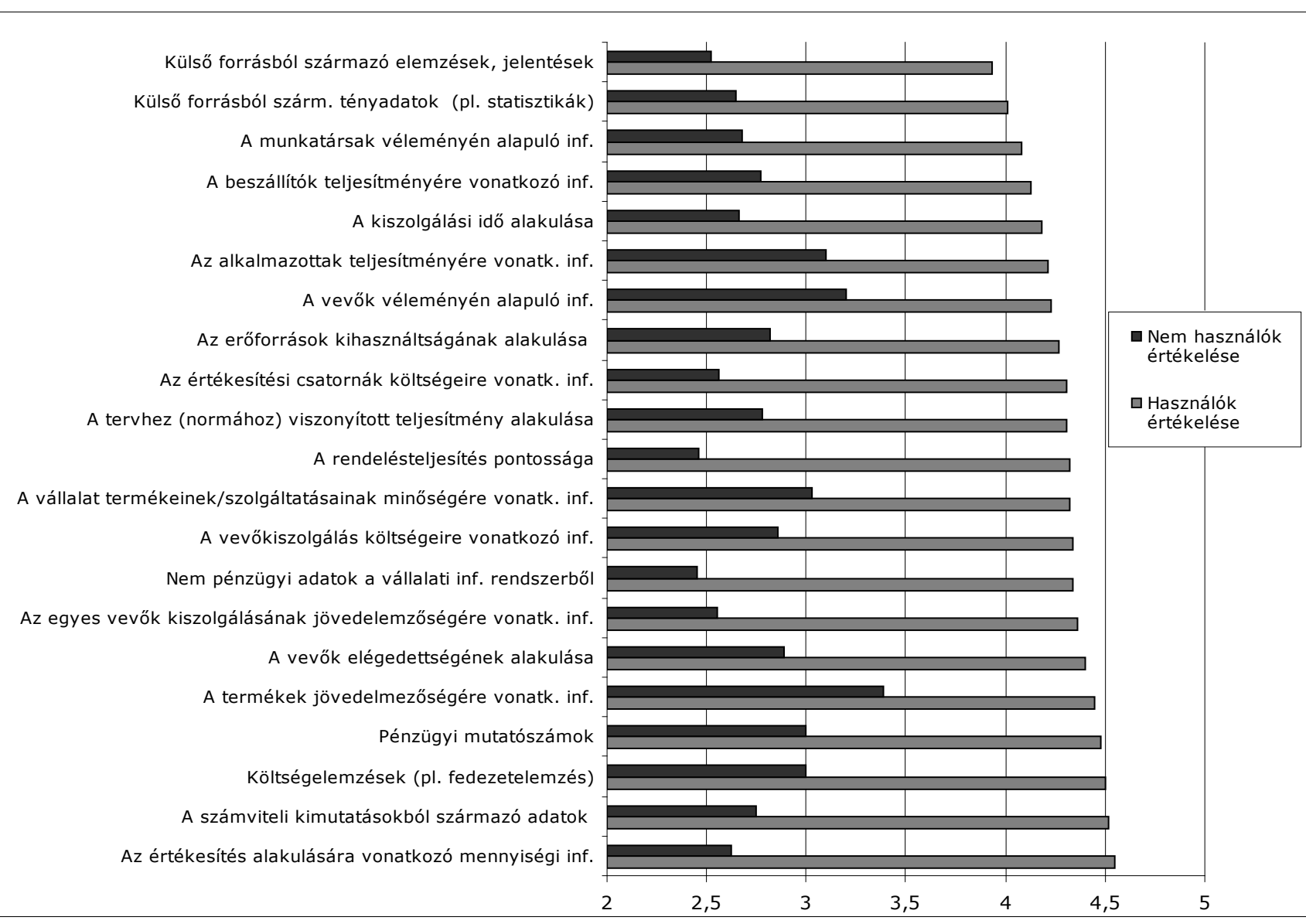

A teljesítménymérés konzisztenciájának további A fizetési ígéretek betartásának fontossága alapján képfontos szempontja a stratégiai céloknak való megfe- zett csoportokban is ki tudunk mutatni szignifikánsan lelés. Elemzéseink során azt is értékeltük, hogy akik különböző́képpen értékelt módszereket (lâsd 9. táblácélként jelöltek meg bizonyos tényezóket (független zat). változók), inkább használják-e a kapcsolódố módszereket, mutatókat (függó̉ változók).

Vizsgáltuk például az egyes vállalatok válaszait a „Milyen prioritást kap az Ön vállalatánál a .... ?" kérdésre (a pénzügyi vezetók által kitöltött kérdóiv kérdése): az egyik csoportba azokat a vállatokent az egyik

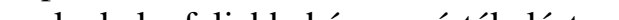
az 1-5 skalan, ing a massik csoportba azo5 , amelyek ćl ez a tényezó fontos (4 vagy 5 a prioritás értékelése). A válaszok alapján szignifikáns kulơnbség mutatható ki például a cash flow-kimutatás értékelésében a két csoport között: azoknál a vállalatoknál, aho a likviditás megórzése, javítása kevésbé fontos, a cash flow hasznosságának átlagos értékelése 3,38, míg a másik csoportban ez 4,00.
A célok és a kapcsolódó teljesítménymutatók kapcsolata: a fizetési ígéretek betartása

\begin{tabular}{|c|c|c|c|}
\hline \multirow{2}{*}{ Mutató (módszer) } & \multicolumn{2}{|c|}{$\begin{array}{l}\text { A módszer értéke- } \\
\text { lése, ha a fizetési } \\
\text { ígéretek betartása }\end{array}$} & \multirow{2}{*}{ 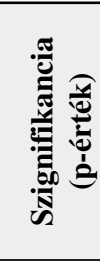 } \\
\hline & $\begin{array}{c}\text { kevésbé } \\
\text { fontos } \\
(\mathbf{1}, \mathbf{2}, \mathbf{3})\end{array}$ & $\begin{array}{l}\text { fontos } \\
(4,5)\end{array}$ & \\
\hline Cash flow-kimutatás & 3,56 & 4,00 & 0,035 \\
\hline $\begin{array}{l}\text { Fix/változó költségek } \\
\text { elkülönítése }\end{array}$ & 3,63 & 4,07 & 0,034 \\
\hline Fedezetipont-számítás & 3,41 & 3,91 & 0,015 \\
\hline Vevốk forgási idejének elemzése & 3,60 & 3,98 & 0,033 \\
\hline Pénzügyi mutatószámok elemzése & 3,50 & 4,15 & 0,002 \\
\hline Cash flow-alapú mutatók elemzése & 3,45 & 3,88 & 0,037 \\
\hline
\end{tabular}

VEZETÉSTUDOMÁNY

A célok és a kapcsolódó teljesítménymutatók kapcsolata a fogyasztók kiszolgálása

\begin{tabular}{|l|c|c|c|}
\hline \multirow{2}{*}{ Tényezó } & \multicolumn{2}{|c|}{ Értékelés azoknál, akik ,a fogyasztók jobb kiszolgálása” } & \multirow{2}{*}{ céjjával } \\
\cline { 2 - 3 } & kevésbé értettek egyet & inkább egyetértettek & \\
\hline Váśrlói elégedettség & 3,83 & 4,43 & 0,002 \\
\hline Vevối reklamációk száma & 3,71 & 4,24 & 0,011 \\
\hline Reklamációkezelés gyorsasága & 3,58 & 4,15 & 0,056 \\
\hline
\end{tabular}

A célok és a kapcsolódó teljesítménymutatók kapcsolata

11. táblázat a vevók elégedettsége

\begin{tabular}{|l|c|c|c|}
\hline \multirow{2}{*}{\multicolumn{1}{|c|}{ Tényezó }} & \multicolumn{2}{|c|}{ Értékelés azoknál, akik ,a vevók elégedettek” céljával } & \multirow{2}{*}{ Szignifikancia (p-érték) } \\
\cline { 2 - 3 } & kevésbé értettek egyet & inkább egyetértettek & \\
\hline Vásárlói elégedettség & 4,13 & 4,45 & 0,033 \\
\hline Vevóii reklamációk száma & 3,92 & 4,27 & 0,036 \\
\hline Reklamációkezelés gyorsasága & 3,72 & 4,18 & 0,011 \\
\hline
\end{tabular}

Valamennyi módszer esetében szignifikánsan hasznosabbnak értékelték ezeket a mutatószámokat azok a vállalatok, ahol prioritást élvez a fizetési ígéretek betartása.

A felső vezetốk válaszai alapján képeztünk két vállalati csoportot aszerint, hogy mennyire értenek egyet azzal, hogy: „Vállalatunk célja a fogyasztók minél jobb kiszolgálása”. A két vállalati csoport (1-3, illetve 4-5 pontos értékelés) között szignifikáns különbség mutatható ki több teljesítménymutató fontossága értékelésében, mint ez a 10. táblázatban látható (10 táblázat).

Ha a vállalatokat a pénzügyi vezetók által megválaszolt kérdés (Vállalatunk teljesítménye pénzügyi szempontból akkor megfelelô, ha a vállalat vevő́i elégedettek) alapján osztjuk két csoportra, akkor is szignifikáns különbséget találunk az előző három módszer értékelésében (lásd 11. táblázat.).

A termelési vezetó által adott válaszok alapján is csoportosítottuk vállalatainkat. A terméktervezés és a minőség változását vizsgáló változó alapján képzett két vállalati csoport esetében szignifikáns különbséget találtunk a termék/szolgáltatás minősége és a rendelésteljesítés pontossága mutatóknál. Mindkét módszernél nagyobb az értékelés átlaga azoknál, ahol pozití irányban változott a terméktervezés. Abban a vállala csoportban, ahol a rendelésteljesítés pontossága javult az utóbbi időben, ott szignifikánsan magasabb a rendelésteljesítésre vonatkozó módszerek értékelése $(3,87$ vs. 4,13).

\section{VEZETÉSTUDOMÁNY}

Összességében a vizsgálatok a versenyképességi felmérések sorozatának eredményeit is tekintve növekvố konzisztenciát jeleznek a teljesítménymérési eszközök használatában, mind a hasznosság megítélése, mind a célokhoz való kapcsolódás tekintetében.

\section{Döntéstámogatás, értékteremtés}

Az értékteremtés, a hatékony döntéshozatal támoatásához tartalmi szempontból kiegyensúlyozott információkra van szükség, melyek figyelembe veszik a különbözố versenytényezốket, figyelemmel kísérik a folyamatokat, s többoldalú, többféle forrásból származó, egymást kiegészító információkat képesek nyújtani. Ebben láthatóan fejlődött a hazai vállalati gyakorlat, s a mindig is fontos pénzügyi információk mellett egyre nagyobb hangsúlyt kap a minőség, s a múködéshez, a vevókiszolgáláshoz kapcsolódó teljesítményelemek. A támogatottság, a kiegyensúlyozottság nem teljes: a

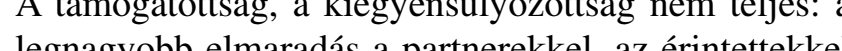
A gyobb elmaradás a partnerekkel, az érintettekke vábbra is.

Mind az érintettek véleményének becsatornázását, mind a feléjük való kommunikációt egyre inkább fontosnak tartják a vállalatvezetốk, ugyanakkor információs rendszereik - a fejlődés ellenére - kevéssé képesek ezt támogatni.

A kontrollinggyakorlatban a hagyományos, belsố forrásból származó, s fôleg pénzügyi információk felhasználása a meghatározó, ugyanakkor növekszik a szubjektív véleményen alapuló illetve a külsó informá- 
cióforrások felhasználása is, ami mindenképpen a több szempontúságot, a teljesebb kép kialakítását segítheti döntéshozatalban

A tizenöt éve folytatott versenyképességi felmérések tendenciját tekintve növekvő következetesség es tudatosság jellemzi a teljesítménymérési gyakorlatot. A pénzügyi és a belsố információk korábbi egyértelmú dominanciája mellett ma már sokkal inkább kihasználják a vállalatok a lehetôségeket, s megjelenítenek különböző versenytényező́khöz, folyamatokhoz, érintettekhez kapcsolódó szempontokat, információk is. Elgondolkodtáó ugyankor, hogy az információs is. Elgondolkodrón az információs rendszer támogató szerepével kapesolatban - a jelentós elörelépés ellenére - nem túlságosan elégedetten nyilatkoznak a válaszacok, no a klasszikus feladatok tekintve sem. Tekinthetjuk ezt persze az elórelépés ösztönzố felismerésnek is, mely segítheti a fejlesztést a jövő́ben.

\section{A teljesítménymérési gyakorlat sajátosságai} néhány vállalati jellemző tükrében

Elemzéseinkben néhány kiválasztott vállalati jellemzố alapján azt is vizsgáltuk, hogy van-e szignifikáns különbség az információs rendszer által nyújtott támogatásban a vezetốk véleménye szerint, illetve eltér-e a vállalatok szemléletmódja a teljesítménymenedzsment

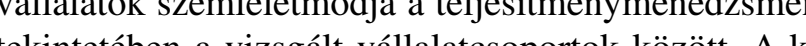
tekintetén sa vizg választout vállalati jellenzok a vállalatteret, a domnáns tulajdonos típusa, a fó tevékenység (iparág), a exportorientáció, a reagálóképesség, a teljesítmény és a piac koncentráltsága.

A következő́kben néhány olyan tényezôt emelün ki, melyeknél statisztikailag szignifikáns különbség mutatható ki a vállalatcsoportok között abban a tekintetben, hogy milyennek értékelik a vezetók az információs rendszer támogató szerepét:

Vállalatméret szerinti különbségek:

- A pénzügyi vezetók szerint az ellenôrzést, beszámoltatást a nagyvállalatoknál támogatja leginkább az információs rendszer (4.24 vs. a kisvállabtok által észlelt 3,8 , illetve a középvállalatok 4,04 értékelése).
altét

- A felső vezetốk a középvállalatoknál jobbnak értékelik a szervezeti egységek közötti kommunikáció, információmegosztás támogatását (átlago értékelés: 4,05), mint a kisvállalatoknál $(3,64)$, illetve a nagyvállalatoknál (3,56). A nagyvállalatoknál a gyengébb támogatás észlelése a felada összetettségéboól, illetve a nagyobb rendszere rosszabb hatékonyságából is eredhet. domináns tulajdonos típusa szerinti különbségek:

- A többségi állami tulajdonban lévő vállalatoknál több esetben szignifikánsan gyengébb különbözố piaci, üzleti kapcsolatokhoz kötốdő tevékenységek információs támogatottsága. A tervezést és a beruházási döntéseket viszont jobban támogatia az információs rendszerük.

- Az egyes vevók jövedelmezőségének az értéke作 cendszere a több́gi állami tulajdon informáós rendszere a tobbségi álami tulajdonban lévố vállalatok vezetói észlelése szerint (2,79 az átlagos értékelés). A támogatás a többségi külföldi tulajdonban lévố cégeknél a legnagyobb $(3,65)$, de a nem állami belföldi tulajdonban lévốknél is magasabb $(3,26)$.

- A beruházási dôntéseket a dominánsan hazai tulajdonban lévő cégeknél támogatja inkább a vállalati információs rendszer (3,72 a többségében állami, 3,6 a nem állami tulajdonban lévố cégeknél). A külföldi tulajdonban lévő vállalatoknál kisebbnek észlelték a támogatást a vezetók $(3,03)$ ami abból is

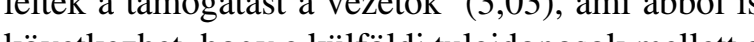

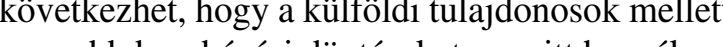
nagyobb beruházási dôntéseket nem itt hozzák.

- A tervezést mind a tobbségi állami $(4,04)$, mind a többségi küllföldi tulajdonban $(4,0)$ lévő́knél jobban támogatja az információs rendszer, mint a hazai (nem allami) tulajdonú vállalatoknál $(3,66)$.

Az üzleti partnerek teljesítményének értékelését a többségi állami tulajdonban lévố cégek információs rendszere nem támogatja megfelelóen $(2,57)$, míg a magántulajdonban lévő cégeknél a támogatottság jobb (3,41 a hazai, 3,33 a külföldi tulajdonban lévóknél)

- Hasonló a helyzet a vevő́i elégedettséggel: a többségi állami tulajdonban lévô cégek információs rendszere nem támogatja (27) a nyomon követéśt, míg a maǵntulajdonba lévố cégekóve-

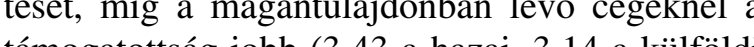
támogatotsăg jobb (3,43 a hazail, 3,14 a külföld tulajdonban lévóknél).

Piaci koncentráció szerinti különbségek:

- A koncentrált piacon múködốknél jobban támogatja az üzleti partnerek teljesítményének értékelését az információs rendszer $(3,64)$, mint a mérsékelten koncentrált $(3,03)$ vagy megosztott piacon $(2,88)$ múködốknél. A megosztott piacon jellemzố nagyobb verseny következménye is lehet, hooy nagyobb figyelem irányul az üzleti partnerek teljesítményére is.

A teljesítménymérési eszközök, módszerek megítélésében a következó szignifikáns elteresek azonosithatók:
A nagyvállalatok vezetői hasznosabbnak tartanak bizonyos költségelemzési módszereket, így a fedezetipont-számítást $(4,47$ pontos átlagos értékelés, szemben a kisvállalatok 3,72-es átlagával) és a költségérzékenységi vizsgálatok használatát (4,44 pontos átlagos értékelés, a kis- és középvállalatok 3,84-es és 3,66-os átlagával szemben).

A vállalatok fó tevékenysége szerint is megfigyelhetốk szignifikáns különbségek: a mező́gazdaságban múködók tartják a legkevésbé haszno nak $\mathrm{pl}$ a cash flow-kimutatást $(3,0)$ a pénzügyi mutatószámok elemzését $(3,17)$, a készletforgás

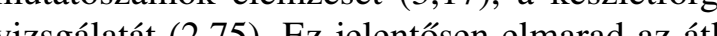
vizsgálatá $(2,75)$. Ez jelentossen elmarad az atlagos êtckelestô (3,91; 4,04; 3,71$)$, s még inkább az act (vegyipar: 4,6; kitermeloipar és energiaszolgált tás: 4,75; kereskedelem: 4,47)

A teljesítménymutatók hasznosságának megítélését nemcsak a szemléletmód, hanem az iparági sajátosságok is befolyásolják: a készletforgás mutatókat a kereskedelemben tartják a legfontosabbnak $(4,47)$, s nem meglepó módon kevésbé itélik hasznosnak a szolgáltató-szektorban $(3,18)$

Az információrendszer támogatása a kïll̈̈böző reagálóképességel jellemzett vállalatcsopơtohban (2009)

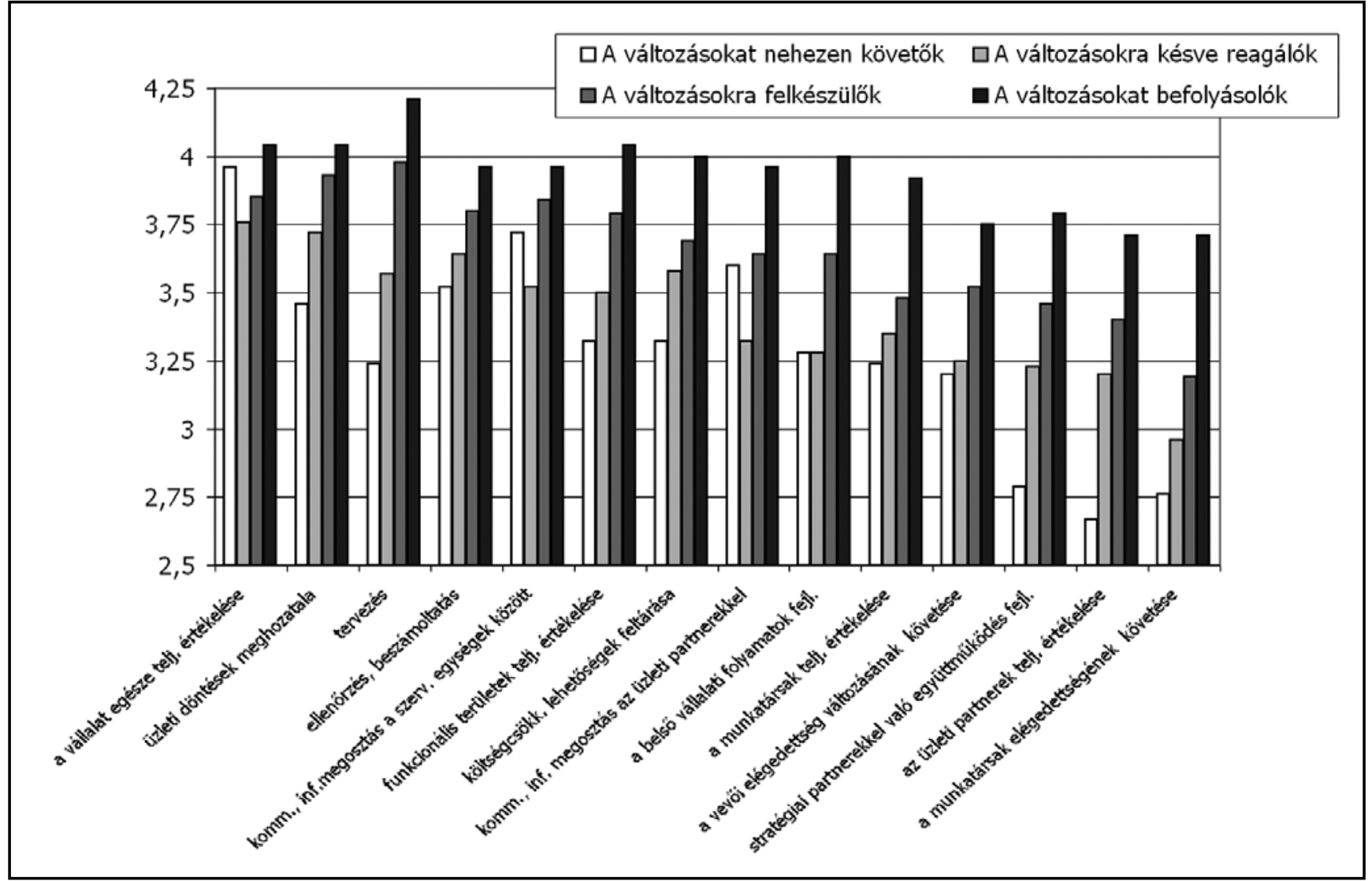

múködốk (bár így is jelentôsen megelózik a mezőgazdasági cégeket: 2,75 ).

Leginkább a vállalati teljesítmény szubjektív (vállalatvezetók általi) megítélése, a változásokhoz való viszonyulás (reagálóképesség), illetve a versenytársakhoz viszonyított teljesítmény alapján képzett vállalatcsoportok esetén tapasztaltunk szignifikáns különbséget az információs rendszer támogató szerepének megítélésében, ezért ezeket a csoportokat részletesebben is bemutatjuk

Aváltozásokhozvalóviszonyulást,reagálóképességet a felsôvezetôi kérdốv egyik kérdésére adott válaszok alapján létrehozott kategóriák szerint értékeltük, melyhogy vállalatuk milyen módon szált szembe a környeA válaszadók legnagyobb része, közel 40\%-a a változásokra késve reagálók csoportí́ba kerïlt, egyharmada a váltoźs változás a t befolý́ lók, s valamivel kevesebb mint egytizedük a változásokat nehezen követók csoportjába sorolható. ben a vezetốk értékelték saját vállalatukat aszerint, zeti változásokkal a 2005-2008 közötti idószakban. 
Szembeötlő, ahogyan ez az 5. ábrán is látható, hogy a jobb reagáló képességgel rendelkezóknél szinte minden területen jobb a támogatás - legalábbis a vezetók észlelése szerint. Két kivételt láthatunk: az egész vállalat teljesítményének az értékelése, illetve a szervezeten belüli, egységek közötti kommunikáció támogatását a változásokra késve reagálók valamivel jobbnak értékelték, mint a változásokra felkészülók, azonban az aktívabb, jobb reagálóképességgel rendelkezók csoportjaiban is magasabb az átlag.

A vállalati teljesítmény szerinti csoportképzés felsố vezetóḱ által adott önértékelés alapión történt. Arra kértïk a felső vezetóket hogy az iparági átlaghoz viszonyítva ́́tćkeljék vállabtok - illetve (több ïzlet-

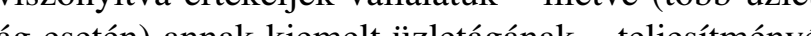
befföldi Osszehas átla , 3 - az iparagi álagszinvonaltó némileg elmaradó, 3 - az iparági átlagszínvonalhoz hasonló, 4 - az iparági átlagszínvonalat némileg meghaladó, 5 - az iparágban élenjáró színvonalat jelentố A következő szempontok szerint: árbevétel-arányo nyereség, tôkejövedelmezőség, piaci részesedés (az át-

Az információrendszer támogatása

a különbözố teljesítménnyel jellemzett vállalatcsoportokban

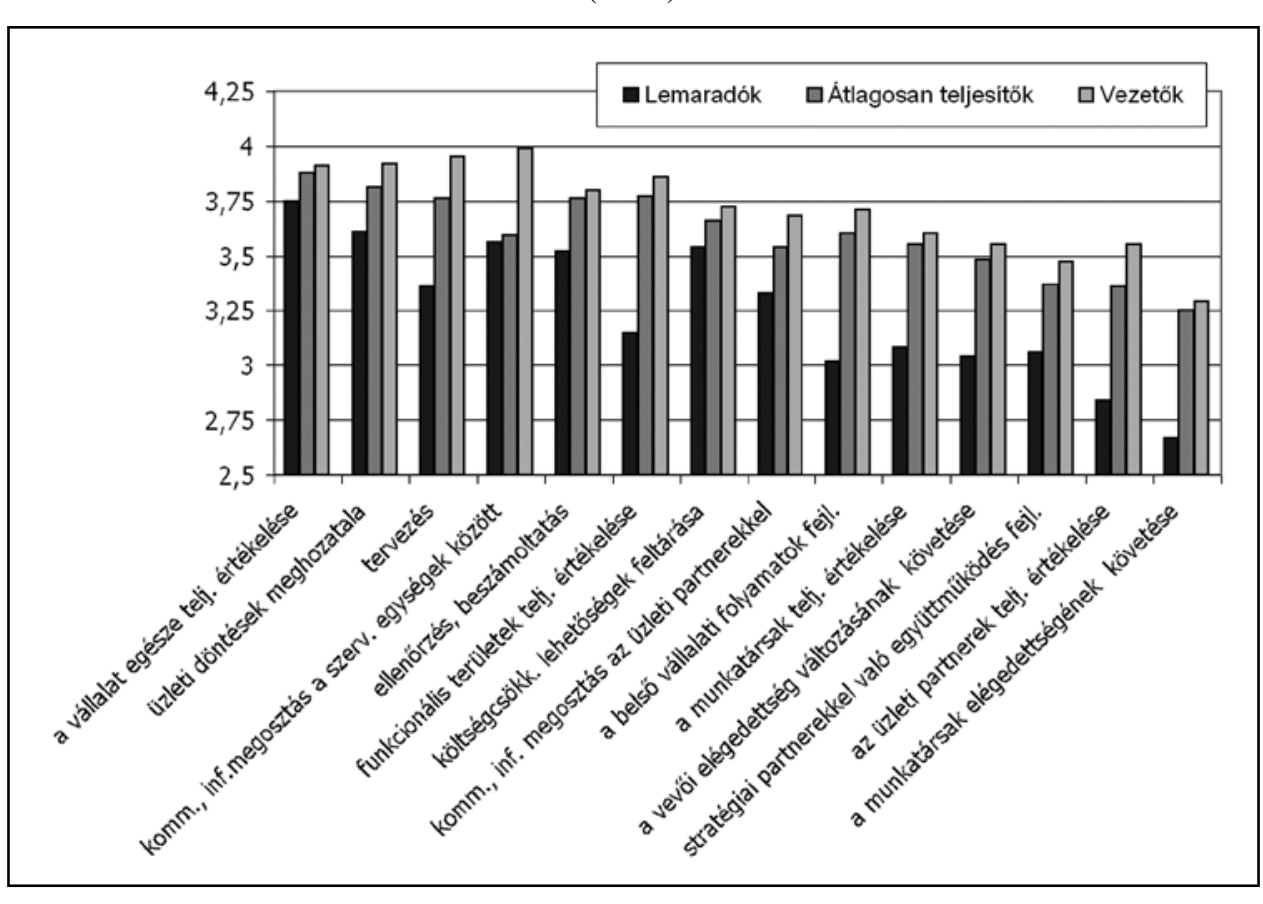

A Lemaradók" csoportiába került a válaszadók csaknem egynegyede. A belföldi iparági átlagnál jobbnak tartott termékminőség és menedzsment mellett az átlagosnál valamivel gyengébbnek tartott technológiai színvonal és átlag alattinak értékelt piaci részesedés és pénzügyi teljesítmény jellemzi ezt a csoportot

A legnépesebb csoport (41,5\%) az „Átlagosan teljesítók" klasztere. Az átlagot meghaladó termékminőség, menedzsment és technológiai színvonal jellemzi ezt a csoportot, átlag körüli piaci részesedéssel, s valamivel jobb jövedelmezőséggel.

A Vezetók" csopotjába tatozik a vál. A „Vzetok" csoporjába tartozik a válaszadók

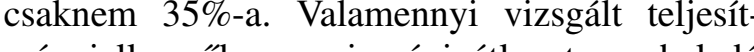
ményjellemzôben az iparági átlagot meghaladó teljesitmeny jellemzi az ide sorolt vallalatokat. Leginkább a termékminôség, a menedzsment és a technológiai színvonal emelkedik ki az iparági átlagból a vállalatvezetók véleménye szerint. A piaci részesedést tekintve ennél kevésbé, $\mathrm{s}$ a jövedelmezőségi mutatók esetében még kisebb mértékben érzékelik az elónyt.

A 6. ábrán látható, hogy a jobb teljesítményt nyújtó Vezetók csoportjában jobbnak értékelték a vezetók nak étékéck a vezetók az infor tán teriileten szinte ninden terileten. Szignifikáns különbség a tervezés és a szervezeti egységek közötti kommunikáció információmegosztás területén volt kimutatható. A vezetốk csoportjában ez utóbbi terület, melynél a legjobbnak értékelték a válaszadók az információs rendszer támogatását, hajszálnyira elmaradva a négyes átlagtól.

\section{Összegzés}

Cikkünkben a vállalati teljesítménymérési gyakorlat döntéstámogató szerepét bevétel alapján), technológiai színvonal, menedzsment, : vizsgáltuk a Versenyképesség-kutatás kérdốives feltermék/szolgáltatás minősége. A válaszok alapján a méréseinek eredményei alapján. Bemutattuk, hogy minta vállalatainak több mint 90\%-a volt besorolható, a vállalati információs rendszerek az ellenốrzést és a klaszterelemzéssel három jól elkülöníthető csoport raj- beszámoltatást támogatják leginkább, a vállalatvezetók zolódott ki:
VEZETÉSTUDOMÁNY s a különböző tevékenységek értékelése változatlanu némileg háttérbe szorul. Fontos kiemelni, hogy az insanileg háter be szorul. Fontos kiemelni, hogy az insem beszélhetünk eróss, hatékony támogatásról az átlagos értékelések alapján.

A korábbi hasonló - de eltérô mintán végzett - felmérések eredményeihez képest egyértelmúnek látszil az információs rendszer döntéstámogató szerepének növekedése, szinte minden területen, különösen a piaci, múködési információk terén. A kontrollingjelentések továbbra is a számviteli kimutatások adataira összpontosítanak, s fókén t belső forrásból információkat tartalmaznak. Elörelépés maznak. Elôrelés cézekethetó a külső információ becsatornázásában, például a vevókkel és a beszállítók nagyobb arányban számoltak be, mint korábban.

nagyobb arányban számoltak be, mint korábban.
A vállalati teljesítménymérés eszköztárát vizsgá va továbbra is a pénzügyi kimutatásokhoz kapcsolódó módszerek a leginkább elterjedtek. A leginkább fontosnak tartott mutatók, a vevói elégedettség és a termékek/ szolgáltatások minőségének mérése használata terjec de fontosságának megítélését is figyelembe véve mé mindig relatív alulméréssel jellemezhetók.

Összességében az elterjedtebb módszereket általában hasznosabbnak tartják a vállalatvezetók mi a kevéssé elteriedteket (másként fog lmazva: a ha a kevessé ér ́últeket többen használják), visza: a ha sznosabok konzisztencia uralkodik tenát. A teljesíménymutató (észlet) hasznosagának és használatának vizsgála alapján relatív túlmérés jellemzi a cashflow-kimutat és a készletforgási mutatơk használatát. Viszonylagos alulmérés észlelhetô a vásárlói elégedettség és a termék/szolgáltatás minősége mellett a vásárlói lojalitás és a rendelésteljesítés idôtartama mérése terén. A 15 éve folytatott felméréssorozatunk eredményeit vizsgálva (hangsúlyozva, hogy a felmért vállalati kör nem azonos, azonban a hasonló módszertan és a mintanagyság lehetôséget ad a tendenciák vizsgálatára) növekvố összhang és következetesség s a döntéstámogató szerep erôsödése érzékelhetố a válaszok alapján.

Elemzéseinkben néhány kiválasztott vállalati jellemzó alapján azt is vizsgáltuk, hogy van-e szignifikáns különbség az információs rendszer által nyúitott támogatásban a vezetốk véleménye szerint, illetve eltér-e a vállalatok szemléletmódja a teljesítménymenedzsment tekintetében a vizsgált vállalatcsoportok között. Néhány esetben volt kimutatható statisztikailag szignifikáns különbség, például a pénzügyi vezetôk szerint az ellenőrzést, beszámoltatást a nagyvállalatoknál támogatja leginkább az információs rendszer. A többségi állami tulajdonban lévố vállalatoknál több esetben szignifikánsan gyengébb különböző piaci, üz- leti kapcsolatokhoz kötődő tevékenységek információs támogatottsága. A tervezést és a beruházási döntéseke viszont jobban támogatja az információs rendszerük. A vállalati teljesítmény önértékelése alapján kialakítot csoportokat vizsgálva a legjobb teljesítményt nyújtó vállalatoknál az információs rendszer szignifikánsan jobban támogatja a tervezést és a szervezeten belüli kommunikációt és információáramlást.

Az értékteremtés, a hatékony döntéshozatal támogatásához tartalmi szempontból kiegyensúlyozott inormációkra van szükség melyek figyelembe veszik kïlönböző versenytényezóket, figyelem keszik (

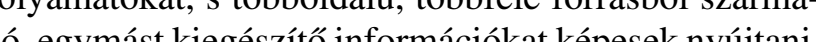
Ebben láthatóan fejlódött a hazai vállabati gy jant, mindig is on pénz a nogyob hanos pénzügyi információk mellett egyre

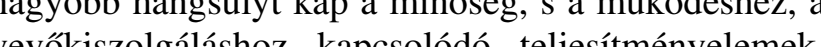
vevókiszolgáláshoz kapcsolódó teljesítményelemek. A támogatottság, a kiegyensúlyozottság nem teljes: a legnagyobb elmaradás a partnerekkel, az érintettekkel való kommunikáció támogatásában figyelhetó meg továbbra is.

Mind az érintettek véleményének becsatornázását, mind a feléjük való kommunikációt egyre inkább fontosnak tartják a vállalatvezetốk, ugyanakkor információs rendszereik ezt - a fejlő́dés ellenére - kevéssé tó-

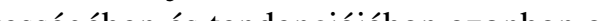
"Öntéstŕm Ö ödése figyelhetó meg a Versenyképestér-kutŕs kapcsolódó felméré az alk zök több sectón zok tobb szenpontúsága s a hasznosság és a stratégiai enpsolón alaján értékelt konzisztenciát egyarán figyelembe véve.

\section{Lábjegyzet}

A cikk a TAMOP-4.2.1.B-09/1/KMR-2010-0005 azonosítójú projektje, A nemzetkozi gazdasági folyamatok és a hazai üzleti szféra versenyképessége címet viseló alprojektjének kutatási tevékenysége eredményeként készüll.

列 hangsúlyt kap az összegyúitiött és rendszerezett információk ak-
tív felhasználásának, s ezáltal a teljesítmény befolyásolásának és fejlesztésének célja. Ezt a fogalomhasználatban megfigyelhetố hangsúlyeltolódás is jelzi a szakirodalomban: a kezdettól használt teljessitménymérés (performance measurement) kifejezés mellett nagyobb hangsúlyt kap a teljesittményfejlesztés (performance improvement) és a teljesítménymenedzsment (performance management) fogalma. Ez is utal arra, hogy a mérés nem öncél, hanem eszkoz: a döntéstámogatás, a kommunikáció, a teljesít sítása már csak azért is szüksséges, mert a korszerúen kialakítot teljesítménymérési rendszerek esetében is elóforduló probléma hogy az eredmények tényleges hasznosítás nélkuil végzik koráb-

\section{VEZETÉSTUDOMÁNY}


ban az irattárban, manapság a vállalati információs rendszerben, nyomtatott vagy csak elektronikus formában összeállított és szétküldött jelentésekben.

${ }^{3}$ Részletesebben tárgyalják a témát a szerzók üzleti teljesítménymérés és -menedzsment módszereinek és szemléletmódjával foglalkozó tanulmányai, pl. Wimmer (2000, 2004, 2005, 2009), Wimmer - Szántó (2006), Wimmer - Csesznák (2011).

${ }^{4}$ A hasonló elemzési keret alapján készült korábbi kutatások eredményei, többek között, a Vezetéstudomány 2004. évi 9. számában jelentek meg (Wimmer, 2004).

${ }^{5}$ A Versenyképesség-kutatás korábbi felmérései során a klasszikus pénzügyi információk (pl. pénzügyi mutatószámok, cash flow) esetében inkább túlmérést, míg a múködési folyamatokhoz, vevớkiszolgáláshoz, vevơi elégedettséghez kapcsolódóan inkább alulmérést azonosítottunk (Wimmer, 2000, 2004). Láthatjuk majd, hogy - a tendenciákat tekintve - az alulmérés csökkent, a leginkább fontosnak tartott mutatók (pl. termék/szolgáltatás minôsége, vevôii elégedettség) mérésének növekvő elterjedtségét tapasztalhattuk a kutatások sorában.

${ }^{6}$ A vállalatcsoportok kialakításának módszerét s a vizsgált vállalati jellemzók kapcsolatát korábbi múhelytanulmányunk tárgyalja (Csesznák - Wimmer, 2011).

${ }^{7}$ A teljesítményklaszterekról részletesebben lásd: Csesznák Wimmer (2011). A teljesítményklaszterek jellemzőit más vizsgálatokban is elemeztük, lásd pl. Mandják - Wimmer - Juhász (2012).

\section{Felhasznált irodalom}

Csesznák A. - Wimmer Á. (2011): Vállalati jellemzők és összefüggéseik a válság időszakában - A ,Versenyben a világgal" kutatási program 2009. évi felmérésében részt vevô vállalatok jellemzése. Múhelytanulmány. Versenyképesség múhelytanulmány-sorozat. 2011. Budapest: BCE Vállalat-gazdaságtan Intézet Versenyképesség Kutató Központ

Chikán A. - Czakó E. - Zoltayné Paprika Z. (szerk.) (2010): Vállalati versenyképesség válsághelyzetben. Gyorsjelentés a 2009. évi kérdőíves felmérés eredményeiról. Budapest: Budapesti Corvinus Egyetem Vállalatgazdaságtan Intézet Versenyképesség Kutató Központ

Dixon, J.R. - Nanni, A.J. - Vollmann, T.E. (1990): The New Performance Challenge - Measuring Operations for World Class Competition. Homewood: Dow Jones - Irwin

Johnson, H.T. - Kaplan, R.S. (1987): Relevance Lost - The Rise and Fall of Management Accounting. Boston: Harvard Business School Press

Mandják T. - Wimmer Á. - Juhász P. (2012): Hálózati pozíció és versenyképesség az üzleti hálózatokban. Vezetéstudomány, XLII. évf. 2. különszám, p. 14-23.

Matyusz Zsolt (2011): A 2009-es versenyképességi adatfelvétel vállalati mintájának alapjellemzői és reprezentativitása. Múhelytanulmány. Versenyképesség múhelytanulmánysorozat. 2011.március. Budapest:BCEVállalatgazdaságtan Intézet Versenyképesség Kutató Központ

Neely, A. - Kennerley, M. - Adams, Ch. (2004): Teljesítményprizma - Az üzleti siker mérése és menedzselése. Budapest: Alinea Kiadó
Schmenner, R.W. - Vollmann, T.E. (1994): Performance Measures: Gaps, False Alarms and „Usual Suspects”. International Journal of Operations \& Production Management, Vol. 14. No. 12, p. 58-69.

Schmenner, R. W. (1997): Some Measures of Concern. in: Dickson, T. (szerk.) (1997): Mastering Management. Pitman Publishing, IMD International - London Business School - The Wharton School of the University of Pennsylvani, p. 302-306.

Szántó R. - Wimmer Á. - Zoltayné Paprika Z. (szerk.) (2011): Döntéseink csapdájában - Viselkedéstudományi megközelítés a döntéselméletben. Budapest: Alinea Kiadó

Wimmer Á. (2000): A vállalati teljesítménymérés az értékteremtés szolgálatában - a pénzügyi és a múködési teljesítmény kapcsolatának vizsgálata, PhD-értekezés, Budapest: Budapesti Közgazdaságtudományi és Államigazgatási Egyetem, Gazdálkodástudományi Kar

Wimmer Á. (2004): Üzleti teljesítménymérés az értékteremtés szolgálatában. Vezetéstudomány, XXXV. évf. 9. szám, p. $2-11$.

Wimmer Á. (2005): Teljesítménymérés és döntéstámogatás az üzleti szférában. Versenyben a világgal 2004-2006 - Gazdasági versenyképességünk vállalati nézôpontból c. kutatás 10. sz. múhelytanulmánya, Budapest: BCE Vállalatgazdaságtan Intézet Versenyképesség Kutató Központ

Wimmer Á. - Csesznák A. (2005): Vállalati jellemzók és összefüggéseik az EU-csatlakozás idején A ,Versenyben a világgal” kutatási programban részt vevő vállalatok jellemzése. 3. sz. múhelytanulmány, Budapest: BCE Versenyképesség Kutató Központ

Wimmer Á. (2009): Teljesítménymenedzsment. in: Demeter Krisztina: Az értékteremtés folyamatai Termelés, szolgáltatás, logisztika. Budapest: BCE Vállalatgazdaságtan Intézet, p. 294-322.

Wimmer Á. - Szántó R. (2006): Teljesítménymenedzsment és értékteremtés az érintettekkel való kapcsolatok kezelése tükrében. Versenyben a világgal 2004-2006 Gazdasági versenyképességünk vállalati nézőpontból c. kutatás 46. sz. múhelytanulmánya, Budapest: BCE Vállalatgazdaságtan Intézet Versenyképesség Kutató Központ

Wimmer Á. (2010): Információk a döntéshozatalban. in: Könczey Kinga - Szántó Richárd - Wimmer Ágnes - Zoltayné Paprika Zita (szerk.): Döntési technikák. Harmadik, bővített kiadás, Budapest: Budapesti Corvinus Egyetem, Döntéselmélet Tanszék

Wimmer Á. - Csesznák A. (2011): Mit mérünk és hogyan? A vállalati teljesítménymérés szemléletmódja és eszköztára a döntéstámogatás tükrében. Múhelytanulmány. Budapest: Budapesti Corvinus Egyetem, Vállalatgazdaságtan Intézet. Versenyképesség Kutató Központ

Cikk beérkezett: 2012. 1. hó

Lektori vélemény alapján véglegesítve: 2012. 5. hó 